\title{
Energy Scenarios: The Value and Limits of Scenario Analysis
}

\author{
Sergey Paltsev \\ Massachusetts Institute of Technology, Cambridge, MA, USA
}

\begin{abstract}
A need for low-carbon world has added a new challenging dimension for the long-term energy scenarios development. In addition to the traditional factors like technological progress, demographic, economic, political and institutional considerations, there is another aspect of the modern energy forecasts related to the coverage, timing, and stringency of policies to mitigate greenhouse gas emissions and air pollutants. Modern tools for the energy scenario development provide a good basis for the estimates of the required changes in the energy system to achieve certain climate and environmental targets. While the current scenarios show that a move to a lowcarbon energy future requires a drastic change in energy investment and the resulting mix in energy technologies, the exact technology mix, paths to the needed mix, price and cost projections should be treated with a great degree of caution. The scenarios are unlikely to be successful at producing precisely definitive estimates, but they can be used as a qualitative analysis of decision-making risks associated with different pathways. If history is any guide, energy scenarios overestimate the extent to which the future will look like the recent past. As future costs and the resulting technology mixes are uncertain, a wise government policy is to target emissions reductions from any source, rather than focus on boosting certain kinds of low-carbon energy.
\end{abstract}

Sergey Paltsev is a Deputy Director of the MIT Joint Program on the Science and Policy of Global Change and a Senior Research Scientist at MIT Energy Initiative and MIT Center for Energy and Environmental Policy Research (CEEPR), Massachusetts Institute of Technology (MIT), Cambridge, USA. E-mail: paltsev@mit.edu 


\section{INTRODUCTION}

Energy scenarios are a useful tool for industry experts, government officials, academic researchers and general public for their policy-making, planning and investment decisions. The scenarios provide projections for a wide range of topics, such as production, consumption, trade, prices, investments, technology mixes, and many others. Energy projections have certain distinct characteristics in comparison to many other sectoral projections. First, energy is used in all sectors of the economy. For example, heating, air conditioning, fueling cars, keeping lights in schools and hospitals, or powering computers, - all these activities and many others need energy in one form or another. Second, energy infrastructure has a long life time. Gas stations, coal-fueled power plants, transmission lines, or natural gas liquefaction facilities are built to last for many decades. Third, energy interacts with the Earth and human environment both locally and globally. $\mathrm{CO}_{2}$ released from combusting fossil fuels, methane leaks from natural gas systems, land impacts from large hydropower projects and oil sands development, health effects from air pollution, - these are just some examples of energy use impacts.

International decisions (e.g., Kyoto Protocol ${ }^{1}$, Paris Agreement ${ }^{2}$ ) that articulate the need to mitigate climate change made energy projections particularly important as these documents call for the future energy system based on a radically different fuel mix in comparison to the historic energy development. Mitigating energy-related greenhouse gas (GHG) emissions (that affect global climate) and air pollutants (that mostly impact local environment) results in substantial challenges and opportunities for the current and future pathways for energy development. Industry experts and policy makers need to understand investment requirements and policy design options and their implications. To combat climate change and air pollution, low-emitting technologies are necessary, and they are likely to transform drastically the energy production and consumption in the coming decades. To answer this challenge, many energy scenarios focus not only on the best guesses about the future paths under the current policy, but they also provide the estimates of the required changes in the energy system to achieve certain climate and environmental targets.

The goal of this paper is to review the value and limits of energy scenarios and, in particular, to assess how the new low-carbon goals are reflected in the latest projections. This relatively new dimension of the scenarios means that in addition to the traditional factors like technology development, demographic, economic, political and institutional considerations, there is another aspect of the modern energy forecasts related to the coverage, timing, and stringency of policies to mitigate greenhouse gas emissions and air pollutants.

Scenario analysis often includes energy paths consistent with various policies. In many cases, it leads to an increase in the uncertainty ranges of the forecasts, while policy makers often prefer to see one number instead of the ranges of outcomes. While academic literature embraces uncertainty, the wide range of outcomes leads to a frequent perception by the general public that the scenarios do not offer much other than a statement that "almost everything is possible". In this paper, we also explore when and where a set of energy scenarios can offer useful information for decision-makers. 
Sometimes the words scenario, projection, prediction, forecast, outlook are used interchangeably, but they all have some nuances in their meaning. To distinguish the wording, MacCracken ${ }^{105}$ defines prediction as a (probabilistic) statement that something will happen in the future; projection as a (probabilistic) statement that something could happen under some conditions; and scenario-based projections as projections of what could happen and not prediction of what will happen. In this paper we use the word "scenario" as a description of what could possibly happen. We use the words outlook and forecast as synonyms of scenario.

\section{TYPES OF ENERGY SCENARIOS}

Energy scenarios are a tool for analyzing the future energy development, to explore the vulnerabilities and seek robust strategies. The scenarios may differ by their geographic coverage (country-specific ${ }^{3}$, regional ${ }^{4}$, global ${ }^{5}$ ), sectoral coverage (industry-focused ${ }^{6}$, energy system-focused ${ }^{7}$, economy-wide focused ${ }^{8}$ ), time horizon (short-term ${ }^{9}$, medium-term $^{10}$, long-term ${ }^{11}$ ), and their basis (model-based ${ }^{12}$, expert-based ${ }^{13}$, expert-based using a range of analytical tools ${ }^{14}$ ). The scenarios also differ by their stated purpose of development. Some scenarios are developed to assess the "most likely" trajectory ${ }^{15}$, while other scenarios provide a so-called Reference Case with a caveat that the developed projections do not imply that they are "likely or desirable"16. Some scenarios describe the trajectories that are required to drive the energy system towards a specific objective such as a particular atmospheric $\mathrm{CO}_{2}$ level ${ }^{17}$, while some other scenarios look at the current policy development to stress that the current trajectory leads to some undesirable outcomes that need to be corrected with future policies ${ }^{18}$. The scenarios are developed by a wide range of public institutions ${ }^{19}$, government agencies ${ }^{20}$, academic researchers ${ }^{21}$, and private companies ${ }^{22}$. Some energy scenarios are updated periodically (usually annually) $3,5,8,14,15$, while other projections come from a one-time publication ${ }^{10,11,12,23}$. Some groups also create "story lines" (e.g, IPCC SRES or Shell ${ }^{7}$ ) that describe the world development qualitatively in addition to the quantitative scenario inputs.

\section{TOOLS FOR SCENARIO DEVELOPMENT}

Most of the scenarios rely on analytical tools of different degrees of complexity. Figure 1 provides an illustration of an analytical system ${ }^{24}$ that has typical elements for the energy supply and demand projections. Usually, such projection systems include energy supply technologies, both fossil fuels and renewables. They also track energy demand categories, such as industrial, residential, transport, etc. Economic growth, population growth, and rate of technological improvement are often based on exogenous assumptions informed by the projections from the leading organizations in these areas such as the International Monetary Fund ${ }^{25}$, UN Population Division ${ }^{26}$, and International Energy Agency ${ }^{5}$. 


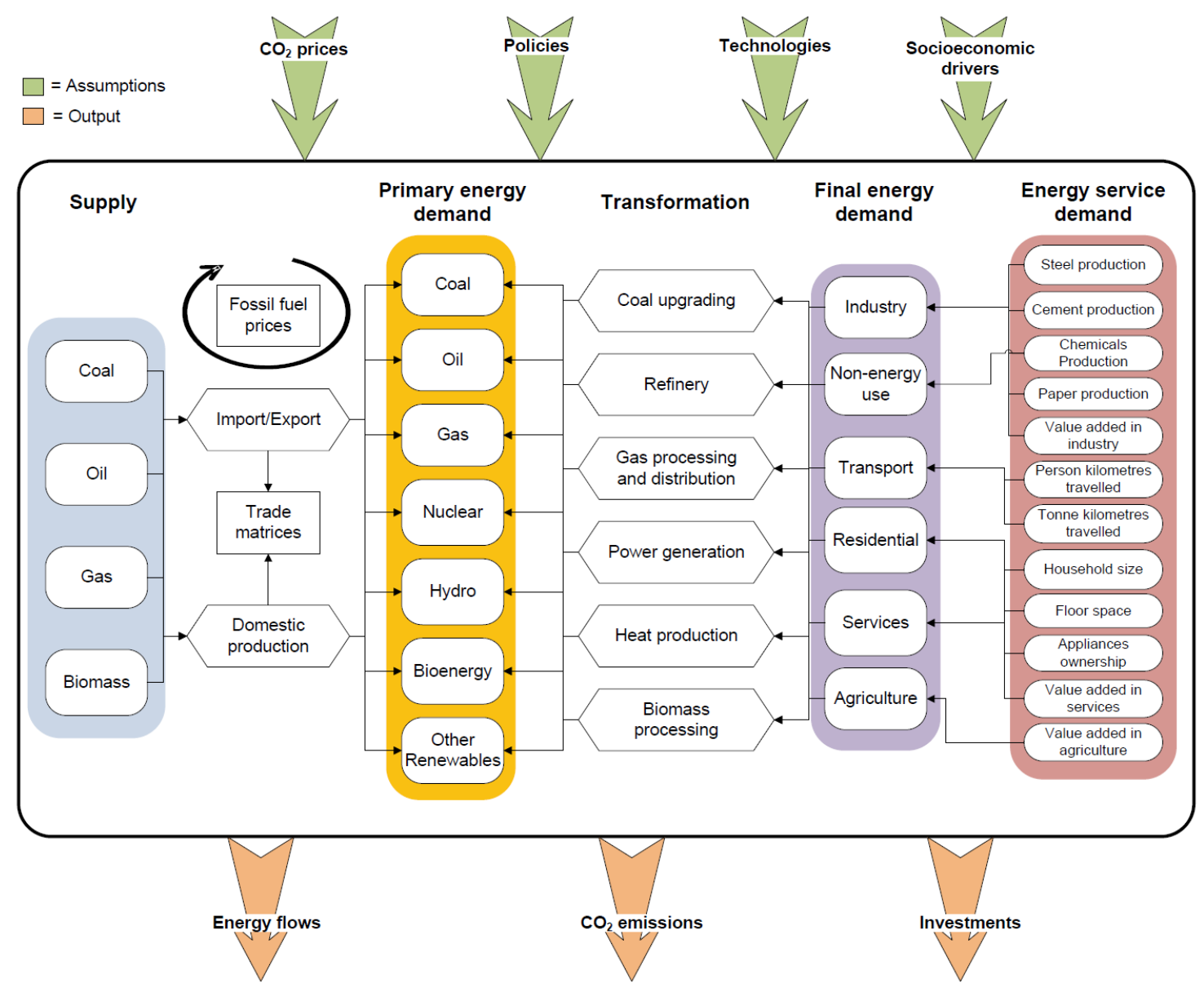

Figure 1. Illustration of the key components of the energy projection system. Figure Source: IEA ${ }^{24}$.

In many relatively simpler systems, fossil fuel prices are assumed, and then energy supply, energy transformation and energy demand are simulated. In more sophisticated systems, fossil fuel prices are determined endogenously. The scenarios usually report energy quantities (e.g., primary energy production and consumption by type), electricity generation by type, energy demand by sector of economy, energy trade flows, investments, and the resulting $\mathrm{CO}_{2}$ emissions. Cost assumptions about energy producing and consuming technologies play an important role for the resulting technology mix.

The tools for scenario development can be focused on a particular fuel (e.g., natural gas ${ }^{27}$ ), the entire energy system ${ }^{24}$, or the whole economy ${ }^{8,28}$. Fuel- or energy-focused models are rich in technological detail but lack economic details and feedbacks from other sectors. They are usually referred to as bottom-up models. Economic models usually represent microeconomic principles (i.e., welfare maximization for consumers and profit maximization for producers), but often lack technological detail, such as physical engineering constraints. These models are usually referred to as top-down models.

A high level of technical details in bottom-up models usually requires a partial-equilibrium perspective, which represents one or several sectors in great detail, but does not capture interactions between these sectors and the rest of the economy ${ }^{29}$. As a result, supply, demand, and 
prices are usually all exogenous inputs to these types of models. The structure and solution approach of these models varies considerably. Most use a linear-programming or mixed-integer programming optimization framework. Some of the most well-known optimization models for electricity and environmental policy analysis are the MARKAL/TIMES model ${ }^{30}$, the National Renewable Energy Laboratory's ReEDS (Regional Energy Deployment System) model ${ }^{31}$, and the International Institute for Applied Systems Analysis (IIASA) MESSAGE model ${ }^{32}$. These models are specifically designed to study the energy and/or electricity sector. They capture multiple regions, time periods, and technologies (typically 20 or more electricity generation technology types).

Bottom-up models typically seek to identify the least-cost method of operating and/or expanding electricity generation technologies in order to meet demand. Assuming perfect information over the total time horizon, capacity expansion and system operation are jointly optimized, accounting for a given life time of technologies. This way, a solution is obtained that features the lowest overall cost (i.e., sum of capital and operational cost). Engineering and operational constraints are often included, such as access to and costs of transmission, the availability and quality of renewable resources, ancillary service requirements and their costs, and physical limitations of operating different types of power plants. When only considering system operation (not investment), dedicated highly detailed models exist. These models operate on a power plant basis, with time resolutions of 1 hour or even 15 minutes. The detail in bottom-up models allows for the explicit and more realistic consideration of how different technologies within the system interact. However, bottom-up models lack an economy-wide framework and therefore cannot provide measures of economy-wide consumption or policy costs.

Top-down models represent economy-wide relationships, can measure social welfare, and are suitable for simulating a wide variety of policies and their impacts ${ }^{29}$. Computable General Equilibrium (CGE) models are a primary type of a top-down economic model. CGE models represent the circular flow of goods and services in the economy. Consumers (households) supply capital and labor services to the producing sectors, which in turn supply goods and services to consumers. The models also represent the reverse flow of payments that corresponds to the flow of goods and services: households receive payments from the producing sectors for the labor and capital services they provide, and, in turn, use that income to pay producers for the goods and services they consume. CGE models track all of these transactions within and across multiple sectors as well as among different regions. Supply, demand, and prices are determined endogenously by all sectors being in equilibrium and all markets clearing.

CGE models focused on energy policy exist at various levels of economic aggregation. At a high level of aggregation is the Dynamic Integrated model of Climate and the Economy (DICE) ${ }^{33}$, and its extensions such as RICE ${ }^{34}$ and ENTICE ${ }^{35}$. These macroeconomic models are built upon the neoclassical Ramsey optimal growth framework, in which growth is driven by capital accumulation and economic equilibrium is reached when the utility function is optimized inter-temporally. These models are highly aggregated, often representing the economy with a single sector or very few, and production of a single final good. Details about the productive inputs (e.g., capital, labor, and energy) are also limited. 
Other economic models follow a more disaggregated, multi-sector economic framework and are constructed from input-output data for the economy. These models are particularly useful for studying the economy-wide impacts of policies as well as sector-specific decisions. Examples are the MIT Economic Projection and Policy Analysis (EPPA) model ${ }^{36}$, the EPA's Applied Dynamic Analysis of the Global Economy (ADAGE) model ${ }^{37}$, and Global Trade Analysis Project (GTAP) Model ${ }^{38}$.

Overall, CGE models are very powerful tools for assessing the economy-wide impacts of policies because they capture feedbacks throughout the economy. While focusing on economic details of market flows, CGE models often make simplifications when it comes to technical detail. Common simplifications are to aggregate sectors, include a subset of representative technologies, and make assumptions about the general impact of details that are not explicitly represented. In the electricity sector, CGE models often lack the full suite of technology options as well as operational constraints such as ramping or transmission congestion. Such details are only implicitly included in the relative costs of the represented technologies.

\section{AN EXAMPLE OF ENERGY SCENARIOS: IEA'S WORLD ENERGY OUTLOOK}

One of the most authoritative sources of energy forecasts is an annual World Energy Outlook (WEO) from the International Energy Agency ${ }^{5}$ that provides a projection of trends in energy demand and supply and what they mean for energy security, environmental protection and economic development. The first WEO was issued in 1994, and the first three outlooks had a projected horizon up to $2010^{39-41}$. In 1997 there was no outlook issued. The 1998-2001 WEOs extended their horizon to 2020 ${ }^{42-45}$. The 2002-2009 WEOs looked up to 2030 46-53. The 2010-2013 WEOs extended their projections up to $2035^{54-57}$, and starting from 2014 WEOs project up to $2040^{58,5}$. The period of projection ranges from 14 years (in 1996 WEO) to 28 years (in 2002 WEO).

IEA uses a combination of approaches in their outlooks. For projecting energy quantities, IEA uses its bottom-up simulation model (see Figure 1), while, to assess fossil-fuel price developments, it relies on its expert opinion. In the latest editions of the Outlook, IEA also uses a top-down model from the $\mathrm{OECD}{ }^{59}$, mostly to provide the trajectory for a carbon-constrained scenario. Information from the WEOs of different vintages can be used to assess how close the projected values are to their actual realized values. Such analysis shows that the projected energy quantities are closer to the projections, especially for aggregates such as global primary energy, than the IEA price forecasts. This can be illustrated by global energy demand and oil price projections. Figure 2 provides the forecasts for the total global primary energy demand from different WEOs. Even a 16-year projection (from 1994 to 2010) was only 10\% off the realized number. A 5-year projection (from 2005 to 2010) was only $2.5 \%$ off. Considering that this period includes a post-Soviet Union collapse in energy use in heavy industries, the acceleration of China's energy demand, a movement from $\$ 20 /$ barrel to $\$ 100 /$ barrel oil prices, the world recession of 2008 (obviously, none of these events were predicted), it is quite remarkable that the aggregate energy needs were projected with a reasonable accuracy. 


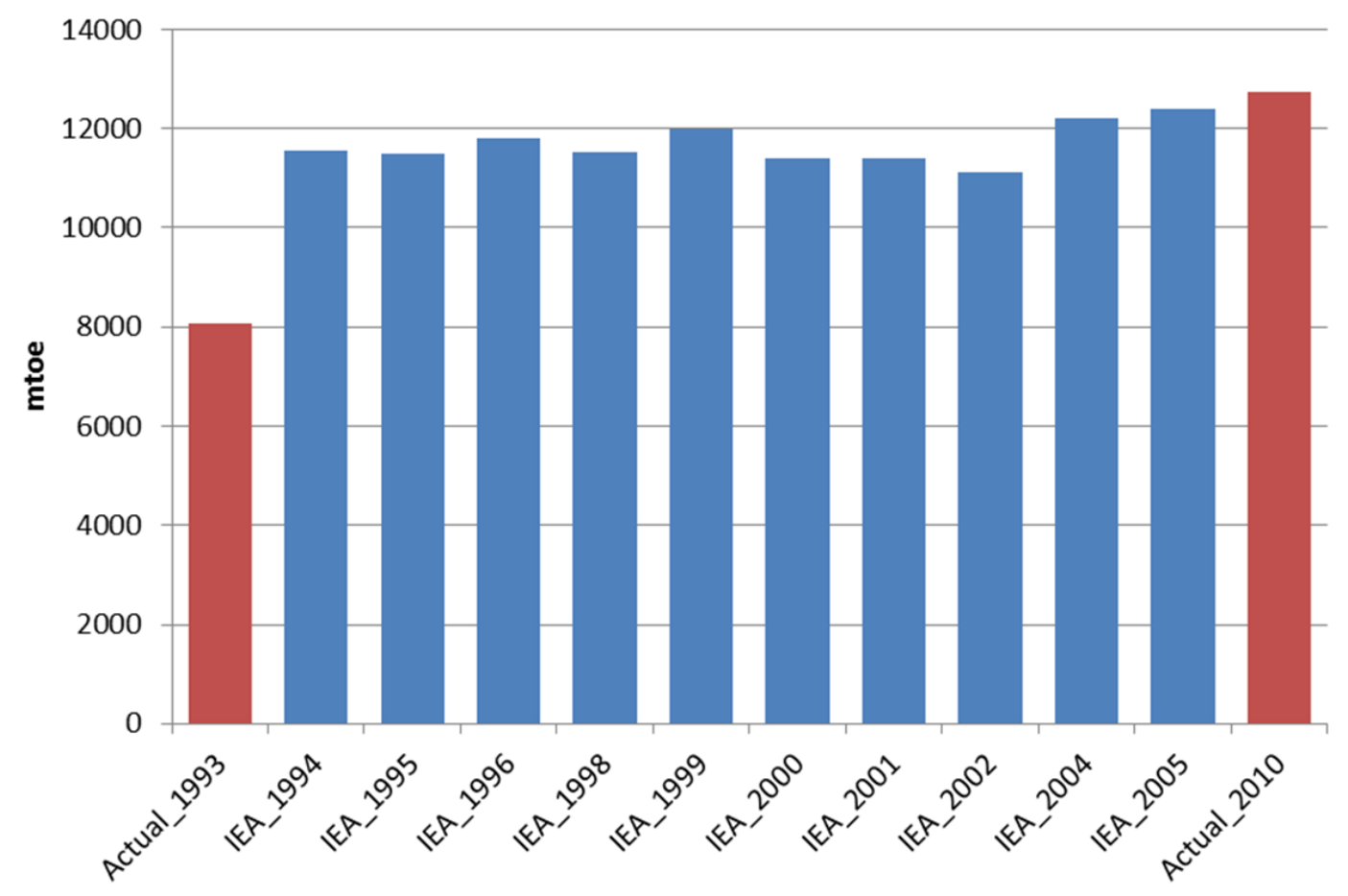

Figure 2. Projected global energy demand for 2010 (in blue) and actual global energy demand for 1993 and 2010 (in red). Data Source: IEA World Energy Outlooks for 1994-2005 ${ }^{39-49}$ (there was no Outlook in 1997 and the 2003 Outlook used 2002 projections).

The record for price projections is not as impressive. Taking an example of oil prices, several years ago the statement from the 1994 WEO that "the reference case projections are based on an assumed average IEA import price of oil of $\$ 17 /$ barrel in 1994 and 1995, rising to $\$ 28 /$ barrel by 2005 , after which it remains flat" would seem like a quite low projection for a price that in 20052010 was actually in the range of $\$ 40-65 /$ barrel (in terms of $1993 \$$ ). The 1994 edition of the WEO made forecasts up to 2010 only. If the forecast were extended, then the projection of low oil price would be closer to the current situation. As of the beginning of 2016, with oil prices less than $\$ 40 /$ barrel, which is about $\$ 25 /$ barrel in 1993 dollars, that 1994 projection is no longer out of place.

Figure 3 shows the projected oil price for 2010 (with all prices converted to 2010 dollars) from different WEOs that made the $\mathbf{2 0 1 0}$ oil price projection. As can be seen from the figure, the price projections were mostly influenced by the oil price in a year before the Outlook issue. The actual 2010 oil price of around $\$ 80 /$ barrel was much higher than most of the projections. The only exception was the 2008 WEO $^{52}$ where IEA decided that the era of cheap oil was over. 


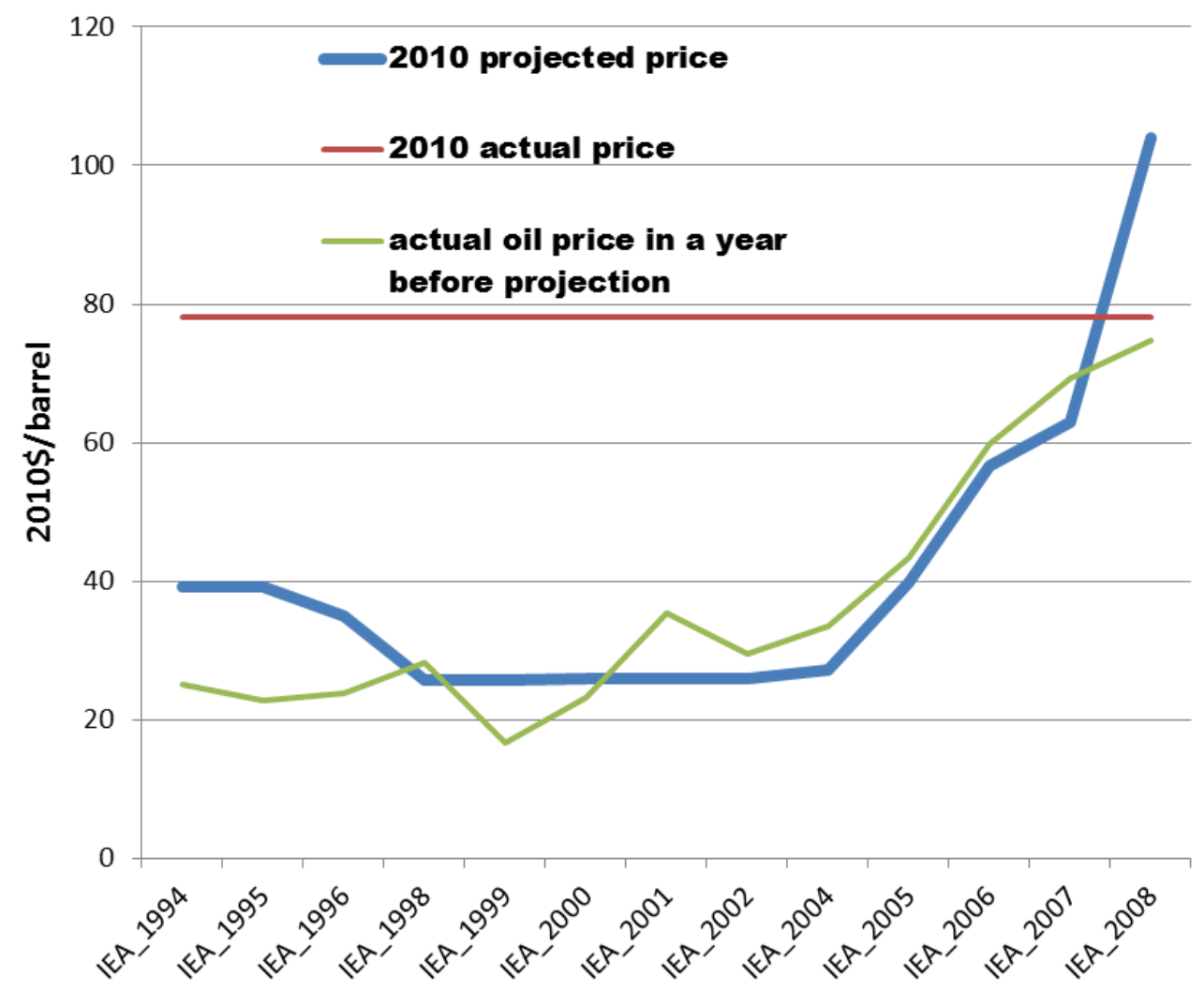

Figure 3. Projected and actual oil price for 2010. Projections are from the IEA World Energy Outlooks for 1994-2008 $39-52$ (there was no Outlook in 1997 and the 2003 Outlook used 2002 projections).

Figure 4 presents information for the 2015 oil price projections. Similarly, most of the projections were based on the oil prices before the corresponding edition of the Outlook was issued. Coincidently, because roughly half of the 2015 projections were issued during the period of relatively low oil prices and the other half - during the period of relatively high oil prices, the 2015 price is in the middle range of the projections from different editions of WEOs. 


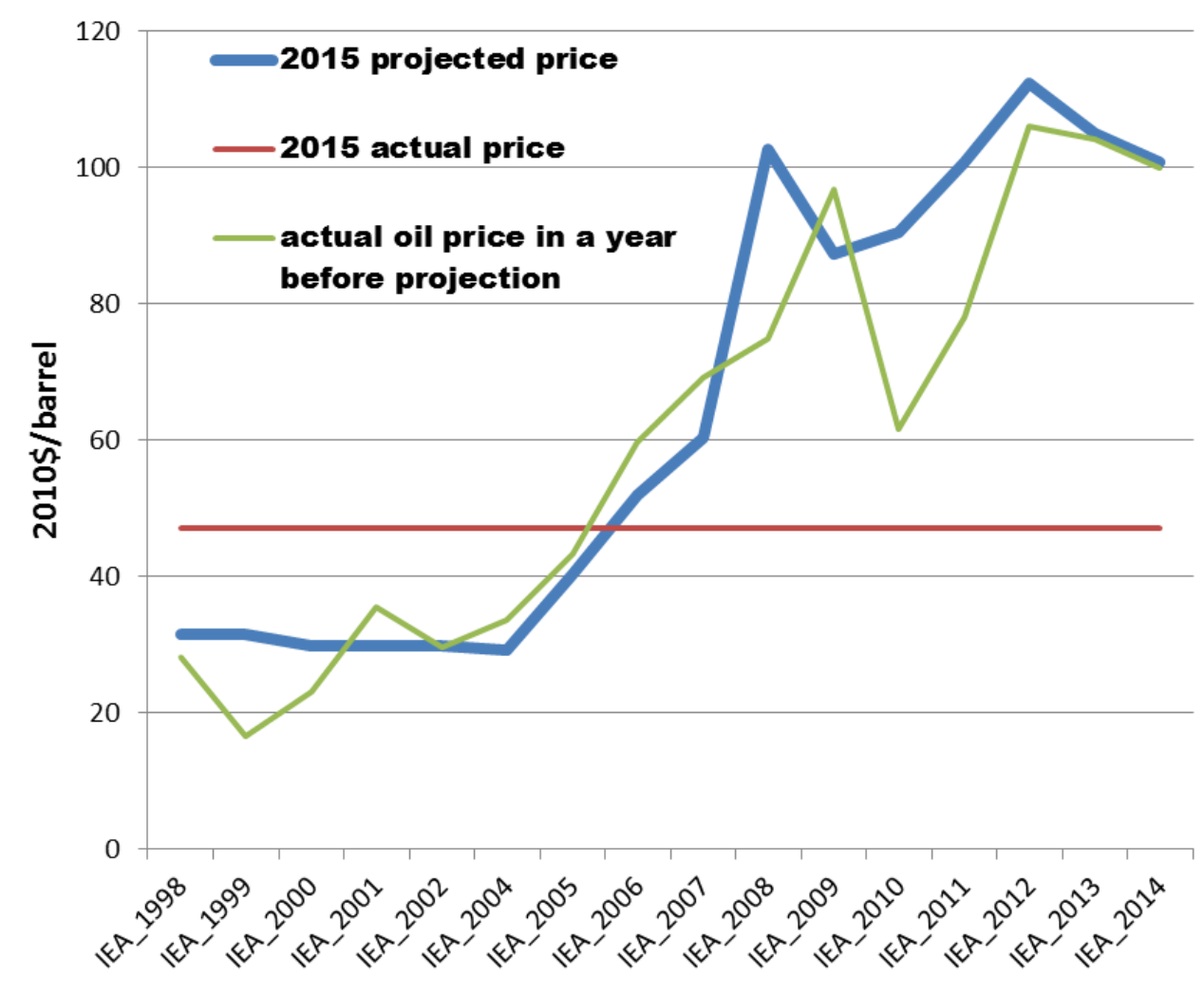

Figure 4. Projected and actual oil price for 2015. Data Source: IEA World Energy Outlooks for 1998$2014^{42-58}$ (the 2003 Outlook used 2002 projections).

In terms of future oil prices, Figure 5 depicts the historic oil price data for 2010-2014 and the projections for 2015-2040 from the two latest IEA WEOs (2014 and 2015) (5,5 $^{5}$ and the latest International Energy Outlook from the U.S Energy Information Administration (EIA), issued in $2014^{60}$. IEA provides three scenarios: Current Policies, New Policies, and the 450 Scenario. The New Policies Scenario (denoted in Figure 5 by a solid black line for the 2015 WEO $^{5}$ and by a solid green line for the 2014 WEO $^{58}$ ) is the central IEA scenario, which is intended to illustrate "the clearest picture possible of the outcome of continuing with the policies that are in place and those that are currently planned" ${ }^{\prime \prime}$. The Current Policies Scenario is a less likely scenario which includes only those policies for which implementing measures had been formally adopted as of mid-2015 and makes the assumption that these policies persist unchanged. The 450 Scenario assumes a set of policies to reduce GHG emissions to limit the rise in the long-term average global temperature to two degrees Celsius. 


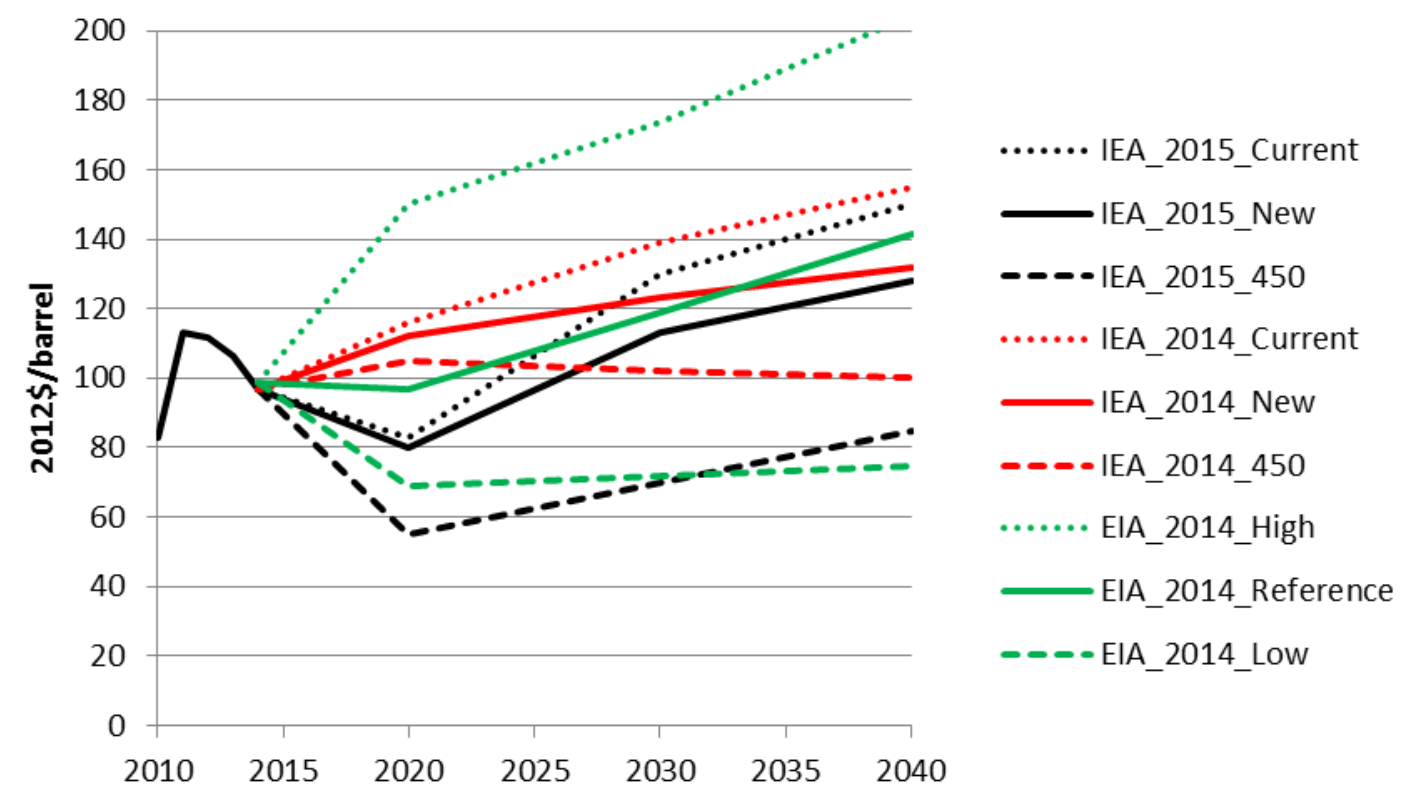

Figure 5. Historic oil prices for 2010-2014 and projected oil prices for 2015-2040. Data source: IEA ${ }^{58,5}$, $E I A^{60}$.

The oil price projection for 2020 in the New Policies Scenario has changed between the 2014 and 2015 IEA outlooks from $\$ 112 /$ barrel to $\$ 80 /$ barrel. The 2015 projection for 2040 is also lower than in the previous outlook: it is reduced to $\$ 128 /$ barrel from $\$ 132 /$ barrel. The 450 Scenario has even more dramatic changes. For 2020, the 2015 projection is $\$ 55 /$ barrel in comparison to the 2014 projection of $\$ 105 /$ barrel. For 2050 , the 2015 projections are $\$ 85 /$ barrel, while the 2014 projection was $\$ 100 /$ barrel. The current (early 2016) oil price is less than $\$ 40 /$ barrel, which is lower than projected oil price in any scenario. As discussed above, oil price projections closely follow the current oil prices; hence, we can expect that the next IEA outlook will have lower price projections.

The 450 Scenario also offers a potential explanation for the current low oil price $(\$ 30-40 /$ barrel in early 2016). Most of the analysts attribute a reduction in oil price to geopolitical considerations (mostly from Saudi Arabia, which tries to keep its share in global oil markets and drive out unconventional oil from the U.S.), slowing down the oil demand increases from China, and technological improvements in oil extraction (mostly from unconventional reserves). There is another dimension that materialized after the UN climate conference in Paris at the end of 2015. Even though, most of the analyses ${ }^{61,62}$ suggest that the Paris Agreement is not going to bring GHG emissions reduction to the levels consistent with the $2^{\circ} \mathrm{C}$ target (as in the IEA's 450 Scenario), the Agreement put in place a global structure for tightening up the emissions reduction over time. As climate policy brings down the prices of fossil fuels ${ }^{63}$, lower oil prices, similar to those projected in the 450 Scenario, become closer to reality. One possible strategy for oil producers, who foresee that fossil fuel resources may become stranded assets in a carbon-constrained world, is to increase production today. Perhaps, it is too early to judge if this consideration plays in the current decisions by major oil producers to increase their oil production despite the decreasing oil prices. 
Figure 5 also shows oil prices for High, Reference, and Low Oil Price scenarios from the US EIA. They have a wider range than the IEA's scenarios. For 2040 the prices in different scenarios vary from $\$ 75 /$ barrel to $\$ 204 /$ barrel. The US EIA projected price for 2040 in the Reference scenario (\$141/barrel) is close to the IEA projections in their central scenario. The next international outlook from EIA is scheduled in 2016. It should be noted that energy outlooks from the industry (e.g., $\mathrm{BP}^{15}$, ExxonMobil ${ }^{14}$, Shell ${ }^{7}$ ) do not report their price projections, rather they focus their projections on physical quantities of energy supply and demand.

\section{ENERGY SCENARIOS: FOSSIL FUEL PROJECTIONS}

Another useful evaluation of energy scenarios is a comparison of fossil use projections from the major 2015 energy outlooks (IEA $\mathrm{A}^{5}, \mathrm{BP}^{15}$, ExxonMobil ${ }^{14}$ ) derived from their respective central scenarios. Such comparison reveals different views to the dynamics of future fossil fuel use. It also underlines different approaches to reporting. For example, even historic numbers for global use are different between the outlooks. Partially, it reflects different assumptions about calorific values of fuels as IEA and BP report their numbers in units of mass - tonnes of oil equivalent (toe), while ExxonMobil uses units of energy - British thermal units (BTU). Approximate conversion from one unit to another may lead to some discrepancies if region-specific values for calorific values are used in actual calculations. There are also variations due to a difference in categories where some fuels are accounted. For example, different outlooks account natural gas liquids in natural gas or oil category, biomass-lased liquids are accounted in oil or in a separate biofuels category, or the products of coal gasification are accounted in coal or natural gas category.

Figure 6 shows that the IEA's outlook for natural gas use is lower both for the historic year (2740 mtoe in 2010 versus 2900 mtoe in 2010 reported by ExxonMobil and BP) and the future projection ( 4000 mtoe in 2035 versus about 4500 mtoe in 2035 reported by ExxonMobil and BP). All outlooks foresee a substantial increase in natural gas use. Oil projections are provided in Figure 7, where again there are some differences in historic data representation. This time ExxonMobil's implied reporting for 2010 ( 4450 mtoe which is an equivalent of 178 quadrillion BTU reported) is larger than the 2010 numbers from IEA (4100 mtoe) and BP (4000 mtoe). All three outlooks envision a slower growth in global oil use than a growth in a global natural gas use. Between 2010 and 2040 natural gas use grows by $55-60 \%$, while oil use grows by $15-30 \%$ in different outlooks. 


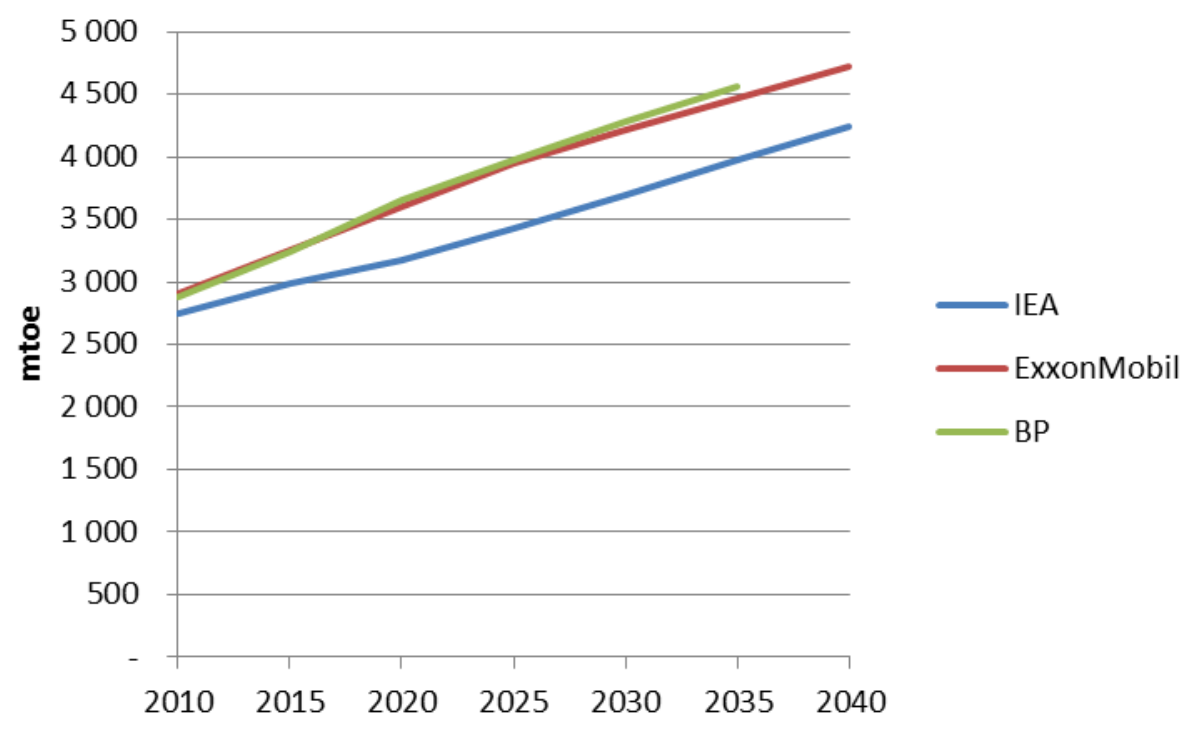

Figure 6. Natural Gas Use Projections. Data Source: IEA ${ }^{5}$, ExxonMobil ${ }^{14}, \mathrm{BP}^{15}$.

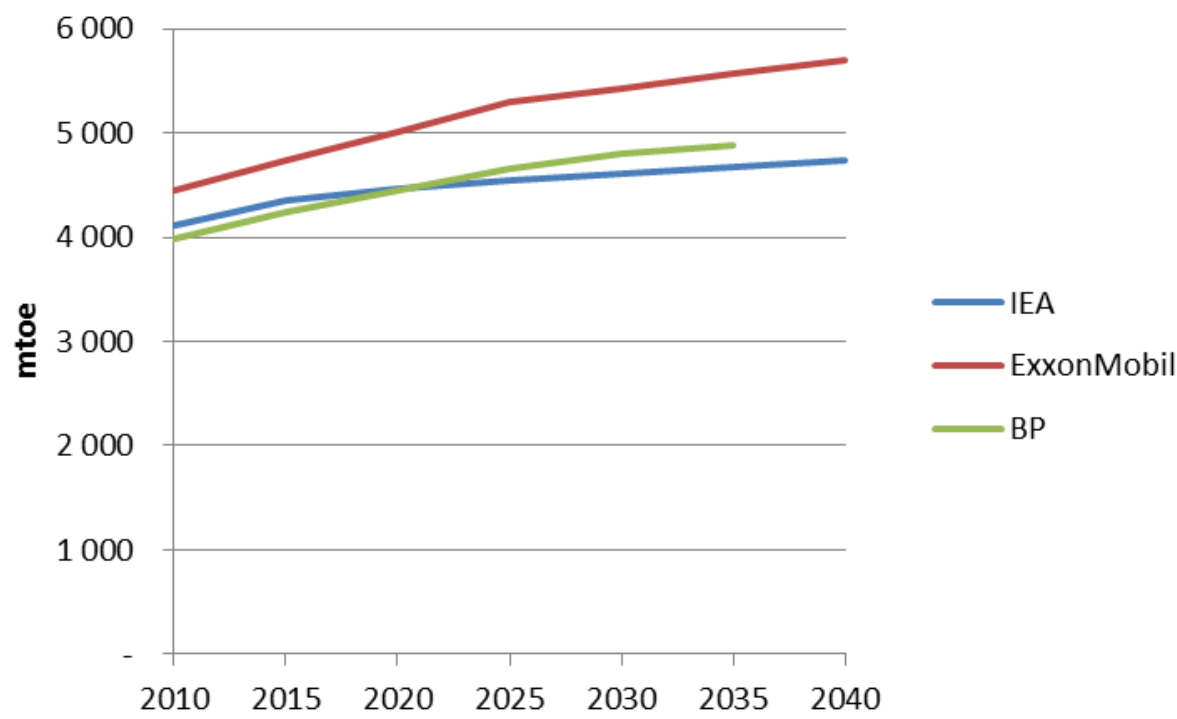

Figure 7. Oil Use Projections. Data Source: IEA ${ }^{5}$, ExxonMobil ${ }^{14}, \mathrm{BP}^{15}$.

Projections for coal use, presented in Figure 8, have a clear difference about the future of coal, mostly driven by the assumed policies to reduce coal consumption. Both IEA and BP prognoses foresee some increases in coal use between 2010 and 2040, but ExxonMobil in their outlook projects a substantial reduction in coal consumption (mostly in OECD countries and China) after 2025. This reduction in the ExxonMobil forecast is driven by substituting from coal to natural gas and renewables in OECD and to nuclear energy in China. The differences in coal forecasts re-iterate an additional degree of uncertainty in the modern energy scenarios - what emission reduction policies 
are assumed and, more importantly, what level of GHG reductions is assumed to be realistic in the "best guess" scenarios.

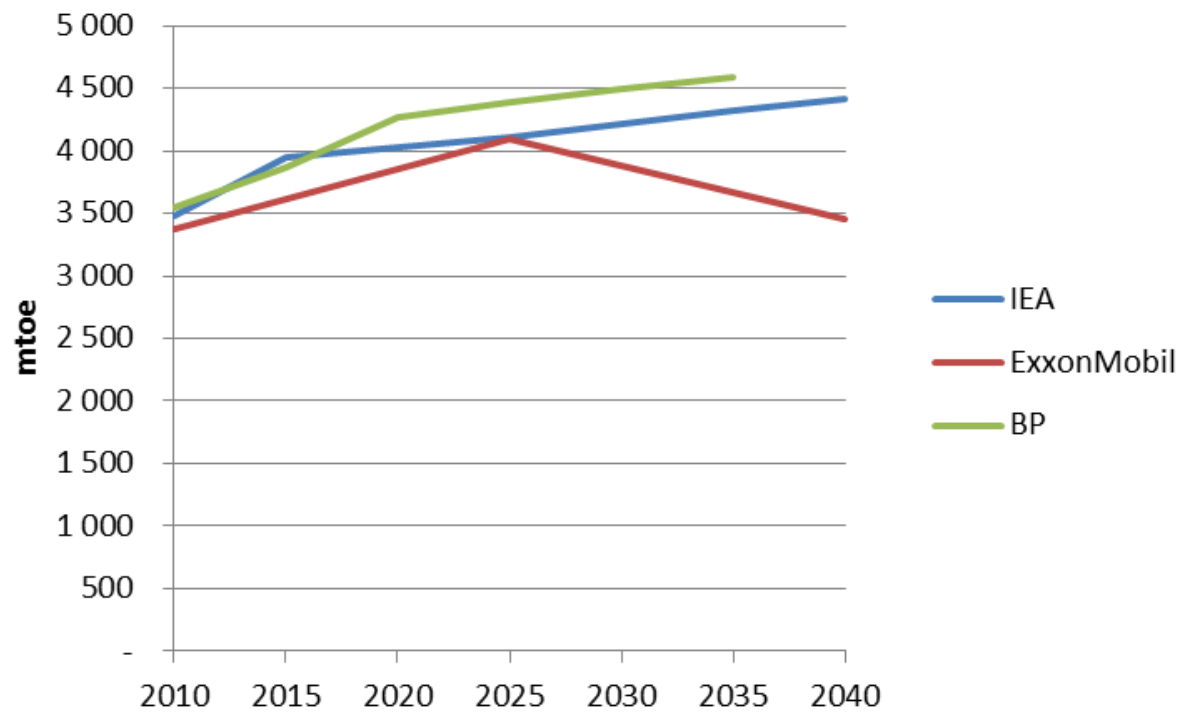

Figure 8. Coal Use Projections. Data Source: IEA ${ }^{5}$,ExxonMobil ${ }^{14}, \mathrm{BP}^{15}$.

\section{ENERGY SCENARIOS: EMERGING TECHNOLOGIES PROJECTIONS}

Another challenging dimension of energy scenarios is an assessment of technological progress and government support for alternative (to fossil-fuels) energy sources, like wind energy, solar energy, bioenergy and others. Figure 9 shows historic data and projections from different IEA $\mathrm{A}^{50-58}$ and US $E_{1} A^{64-66}$ outlooks for a cumulative solar power capacity ${ }^{67}$. The projections are revised upwards over time, but actual installed capacity consistently exceeds the projections. For example, the 2006 IEA WEO $^{50}$ forecast about $100 \mathrm{GW}$ of solar capacity in 2030, while the 2014 IEA WEO ${ }^{58}$ projects more than $500 \mathrm{GW}$. The data from IEA provide a longer time series, but a similar tendency can be found in other periodic outlooks, where the new editions of the forecasts revise solar generation capacity projections upwards. These increases start from a small base, so it is not clear if the future growth will be even faster than currently envisioned, or the issues related to intermittency and reduced government support may slow down the future growth.

Renewable sources have lower than fossil-based generation capacity factors (i.e., periods of time when electricity is actually generated) due to their intermittency. Sun does not always shine, wind does not always blow, and in many countries their current electric grid is not design to accept very large quantities of power from intermittent sources. Hence, a large installed capacity of renewable energy sources is not always proportional to the large numbers for power generation from these sources. There are numerous studies that assess the ways to deal with intermittency, such as storage technology, better designed electric grid, power demand management, better forecasts of wind and solar availability ${ }^{67}$. Uncertainty in a pace of solving intermittency issues adds to a difficulty 
of projecting the energy contribution from the emerging technologies, such as wind and solar power generation.

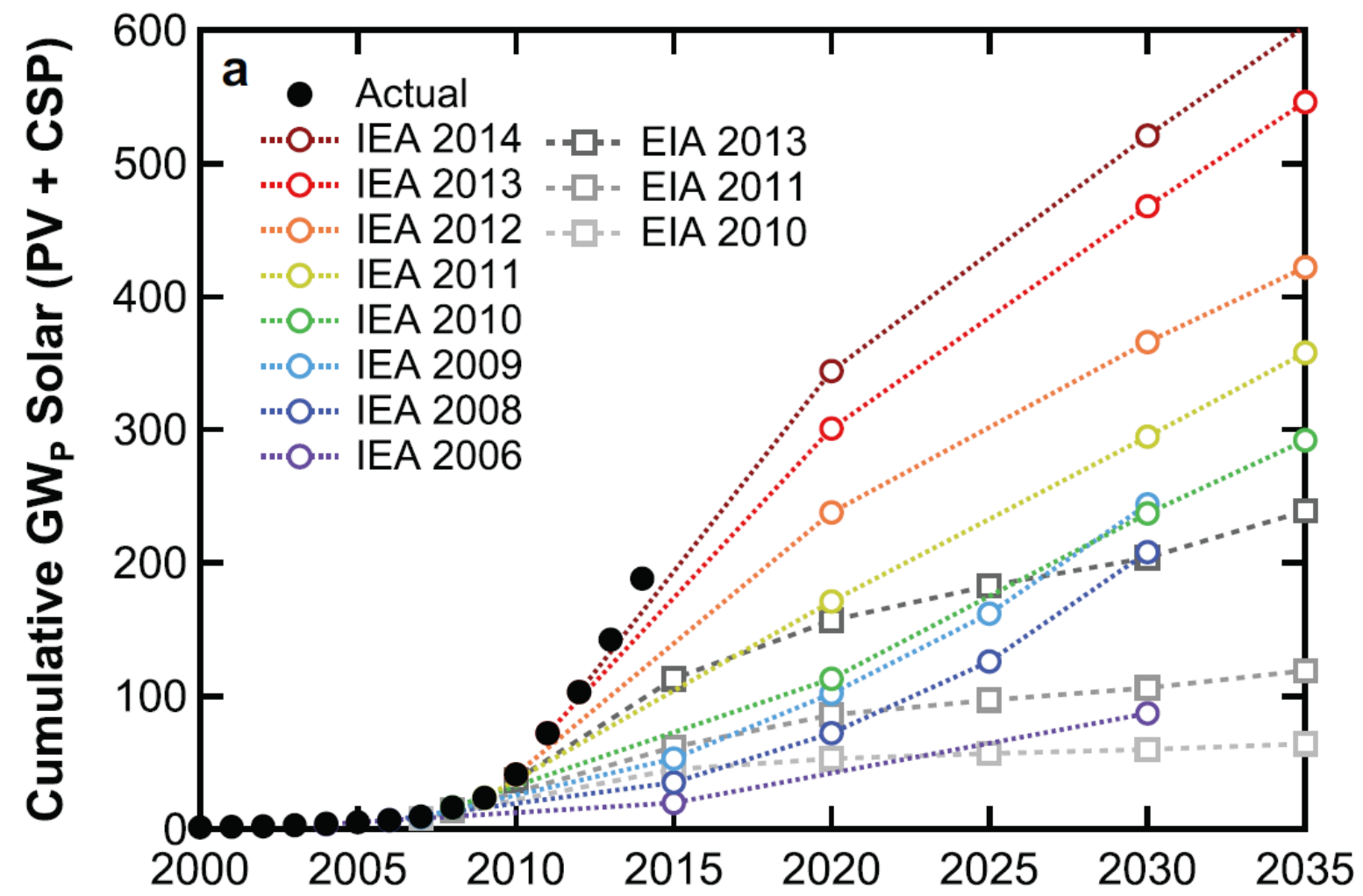

Figure 9. Historic data for installed solar generation capacity in 2000-2014 and projections for 20152035. Figure Source: MIT ${ }^{67}$.

Similarly to capacity projections, current forecasts for wind power generation show an underestimation relative to actual historic generation, as represented in Figure 10. The last available IEA data ${ }^{5}$ for wind power generation are for 2013, when 635 TWh were generated globally from wind resources. The 2006 edition of the IEA WEO ${ }^{50}$ was projecting that amount of global wind generation only by around 2020, so the realized number came seven years earlier than projected. Over time, projections for wind are also revised upwards. For example, a projection for 2030 is twice as large in the 2015 IEA WEO $^{5}$ (2535 TWh) in comparison to the 2006 IEA WEO ${ }^{50}$ projection (1132 TWh). Similar under-predicting is relevant for solar power generation. There is a substantial body of literature that discusses the intermittency and integration issues for the renewables like wind and solar at higher penetration rates ${ }^{68-70}$. So far, in the 2015 WEO projections for the central IEA scenario (New Policies Scenario), the 2040 share of wind and solar generation is about $15 \%$ of total global electricity generation. Even in the more aggressive 450 Scenario, the share of wind and solar is about $25 \%$ globally. Some regions have a larger share of wind and solar power in their generation mix in this scenario in 2040, like the EU with a share of about $37 \%$ (in the central case the EU's share is $29 \%$ ) and the U.S. with a share of about $30 \%$ (17\% in the central case). If the current trend of under- 
predicting renewable generation continues, the future might see larger shares of renewables earlier than currently projected.

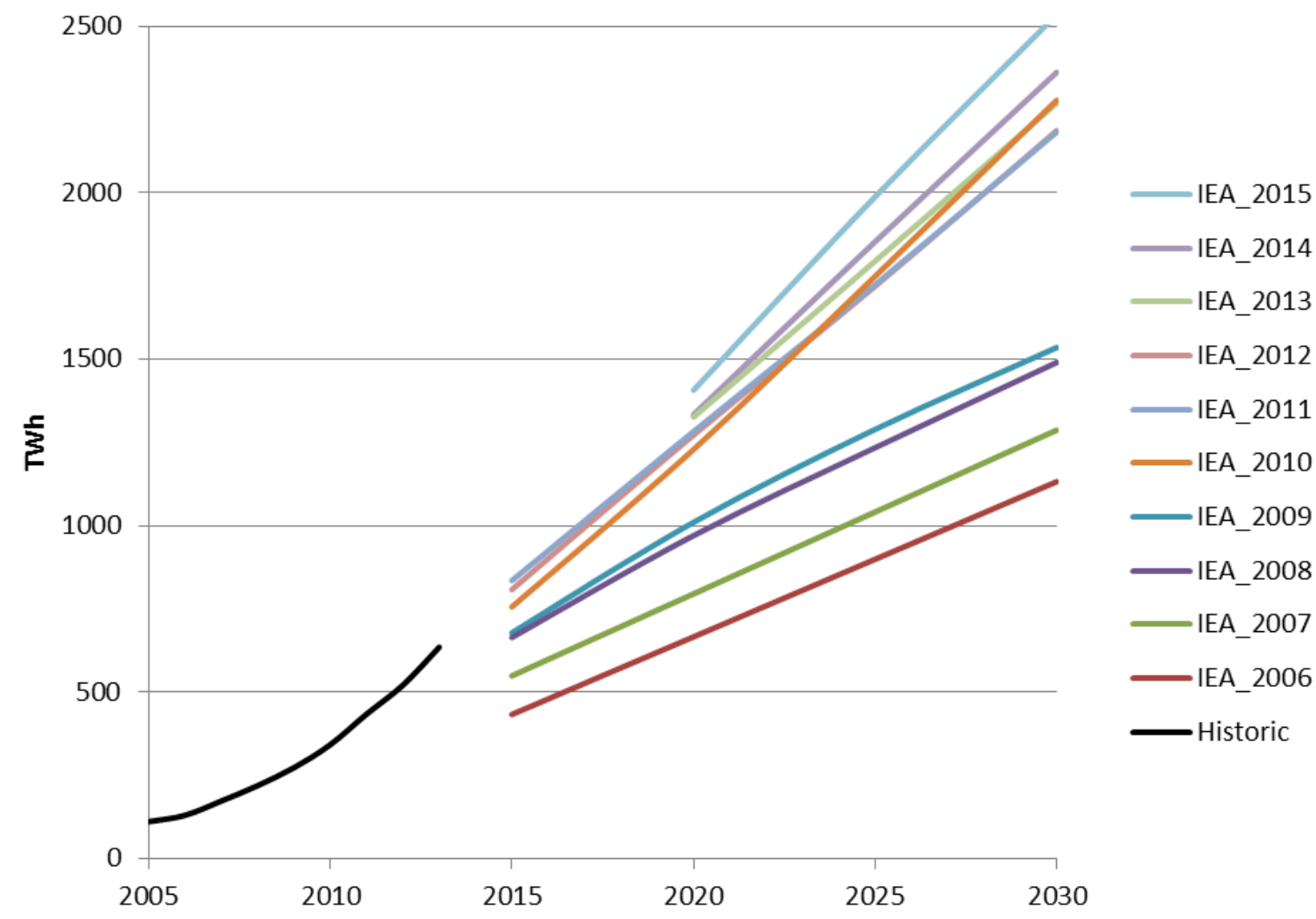

Figure 10. Historic data for global wind power generation in 2005-2013 and projections for 20152030. Data Source: IEA WEOs from 2006-2015,50-58.

\section{LONGER-TERM SCENARIOS: EARLIER PROJECTIONS}

One of the first comprehensive analyses of the future energy use was done by Edmonds and Reilly ${ }^{71}$ in their 1985 book where the energy-emissions model is employed to provide a consistent approach to developing energy scenarios. In their study up to 2050 a wide range of energy technologies is covered: conventional and unconventional oil, conventional and unconventional gas, coal, nuclear, hydro, solar, wind, and biomass. Figure 11 provides a comparison of their global primary energy projections (on the left panel) with the historic data for 1975, 2000, and 2013 and projections for 2025 from the latest IEA outlook ${ }^{5}$ in the Current Policies Scenario. Most notable differences are in the coal use projections. Converting the numbers to the same energy reporting approaches, Edmonds and Reilly projected the following energy mix for the year 2000: coal - 152 exajoules (EJ), oil - $154 \mathrm{EJ}$, natural gas - $82 \mathrm{EJ}$, nuclear, hydro and other sources - $97 \mathrm{EJ}$, while the historic numbers for 2000 reported by IEA are: coal - 95 EJ, oil - 144 EJ, gas - 84 EJ, nuclear, hydro and other sources 
- 130 EJ. Apart for missing a slowdown in coal use, other fuels were projected remarkably close to the actual numbers. It is a quite amazing result because a period of 1990 s contains considerable geopolitical changes that affected energy patterns: the break-up of the Soviet Union and the acceleration of China.
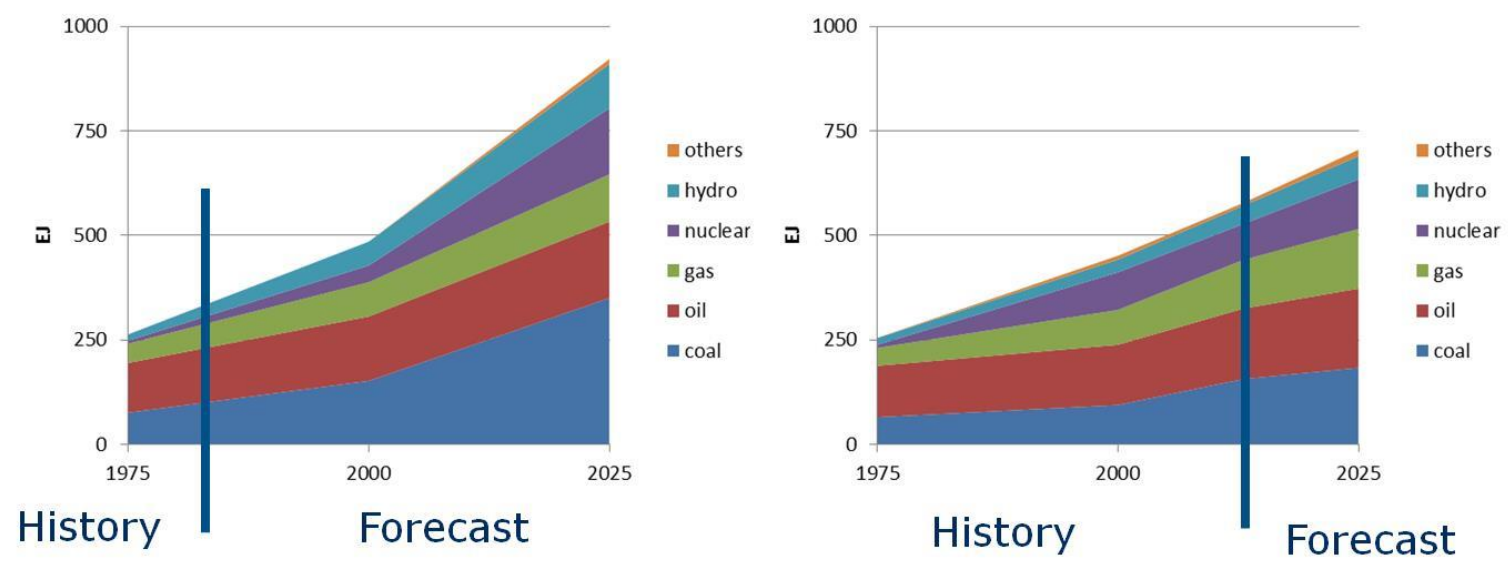

Figure 11. Global total primary energy use: historic data and projections from the Edmonds-Reilly study (left panel), and from 2015 IEA WEO (right panel). Data Source: Edmonds and Reilly ${ }^{71}$ and IEA ${ }^{5}$.

The projections for 2025 deviate more between Edmonds-Reilly and IEA. While oil projections for 2025 are still astonishingly close (183 EJ from 1985 forecast by Edmonds-Reilly and 190 EJ from 2015 forecast by (EA), their growth in coal use is over-predicted and a growth in natural gas use is underpredicted in comparison to the current IEA forecast from 2015. A relatively recent shift from coal to natural gas was not predicted in the 1985 analysis. In terms of other differences, the 2015 IEA projections for total primary energy use and hydropower development for 2025 also look more modest in comparison with the forecasts from the 1985 study. Edmonds-Reilly's forecast for 2050 envisions even faster total energy use growth for the 2025-2050 period in comparison to their projected 2000-2025 growth, reaching 1650 EJ in 2050 from 920 EJ in 2025. IEA projects about 600 EJ in 2020, $700 \mathrm{EJ}$ in 2030, and $785 \mathrm{EJ}$ in 2040 for the total energy use, which a substantially slower energy use growth, driven mostly by a slower coal use in comparison to Edmonds-Reilly forecast. Interestingly, while discussing regional trends, Edmonds-Reilly book projects a falling global energy share for the USSR and a rising share for China, which turned out to be the realized trends, and they happened even at a faster pace. Of course, in their projections for 2050 the Soviet Union still exists, which again brings the point that forecasts are less suitable for projecting sudden changes.

The 30-year-old forecast by Edmonds-Reilly provides some observations relevant to the assessment of the long-term energy scenarios. It seems that due to a long-lasting nature of energy infrastructure the projections for the total energy use for the next 20-30 years are not far off the realized numbers based on the assumptions of population growth, economic growth, labor productivity, and energy efficiency improvements. However, regional numbers diverge more than global projections. Both Edmonds-Reilly study and the earlier IEA outlooks have under-predicted China's growth in energy use and over-predicted energy use growth in USA and Europe. At the same time, the projected total 
global numbers are not that indecent, perhaps suggesting that these changes in regional energy use were driven by a relocation of energy-intensive industries from USA and Europe to China rather than by the changes in total global energy demand. The future forecasts may also miss a potential further relocation of energy-intensive industries to, let us say, Africa or the Middle East in the next 50 years, but the global demand might not be as affected. Of course, there is also a possibility that new climate policies will affect energy prices in a substantial way, and the global energy use would be also quite different in the future in comparison to the world where less stringent climate policy implemented. Looking at the lower global energy use in the current projections, one might also see a larger role for improvements in energy efficiency than envisioned in the earlier studies. Another area of under-prediction is the rate at which new technologies enter the mix.

\section{LONGER-TERM SCENARIOS: CLIMATE-POLICY RELATED PROJECTIONS}

There are many studies that call for a greater integration of energy and climate and economic policy ${ }^{72-76}$. An analysis of such integrated climate-related policies requires even longer-term energy projections, sometimes up to 2100 . A recent IPCC assessment report (AR5) ${ }^{77}$ contains a scenario database ${ }^{78}$ with 1,184 scenarios published in peer-reviewed literature. In the database, 392 scenarios were designed to be consistent with the climate stabilization goal of no more than $2^{\circ} \mathrm{C}$ increase relative to pre-industrial level. Figure 12 provides trajectories for the global total primary energy use in these $2^{\circ} \mathrm{C}$ scenarios. Due to a large number of scenarios covering a wide range of outcome, these typical projections from a climate policy related literature are sometimes referred to as "spaghetti diagrams". Policy-makers that embrace certainty sometimes have a difficult time with these "all over the place" forecasts.

In addition, some of the projections are based on the data from 1990s or 2000, so 2005 and 2010 are projected years for some earlier published scenarios. In the AR5 database ${ }^{78}$, there is a range for the 2005 value of primary energy between $408 \mathrm{EJ}$ and $479 \mathrm{EJ}$, which is partly explained by different base year values used by different models and partly by a deviation of the projected numbers from the realized value for the global primary energy use. In 2010 the range of the values is from $427 \mathrm{EJ}$ to $523 \mathrm{EJ}$. The ranges can be compared with the corresponding historic numbers from IEA ${ }^{5}$, which is $458 \mathrm{EJ}$ in 2005 and $510 \mathrm{EJ}$ in 2010 (the IEA historic data and projections are not included in the AR5 database because the IEA outlooks are not in peer-reviewed literature as required by IPCC for inclusion in its assessment). So far, the realized values are closer to the upper bound of the energy projections for the long-term models. 


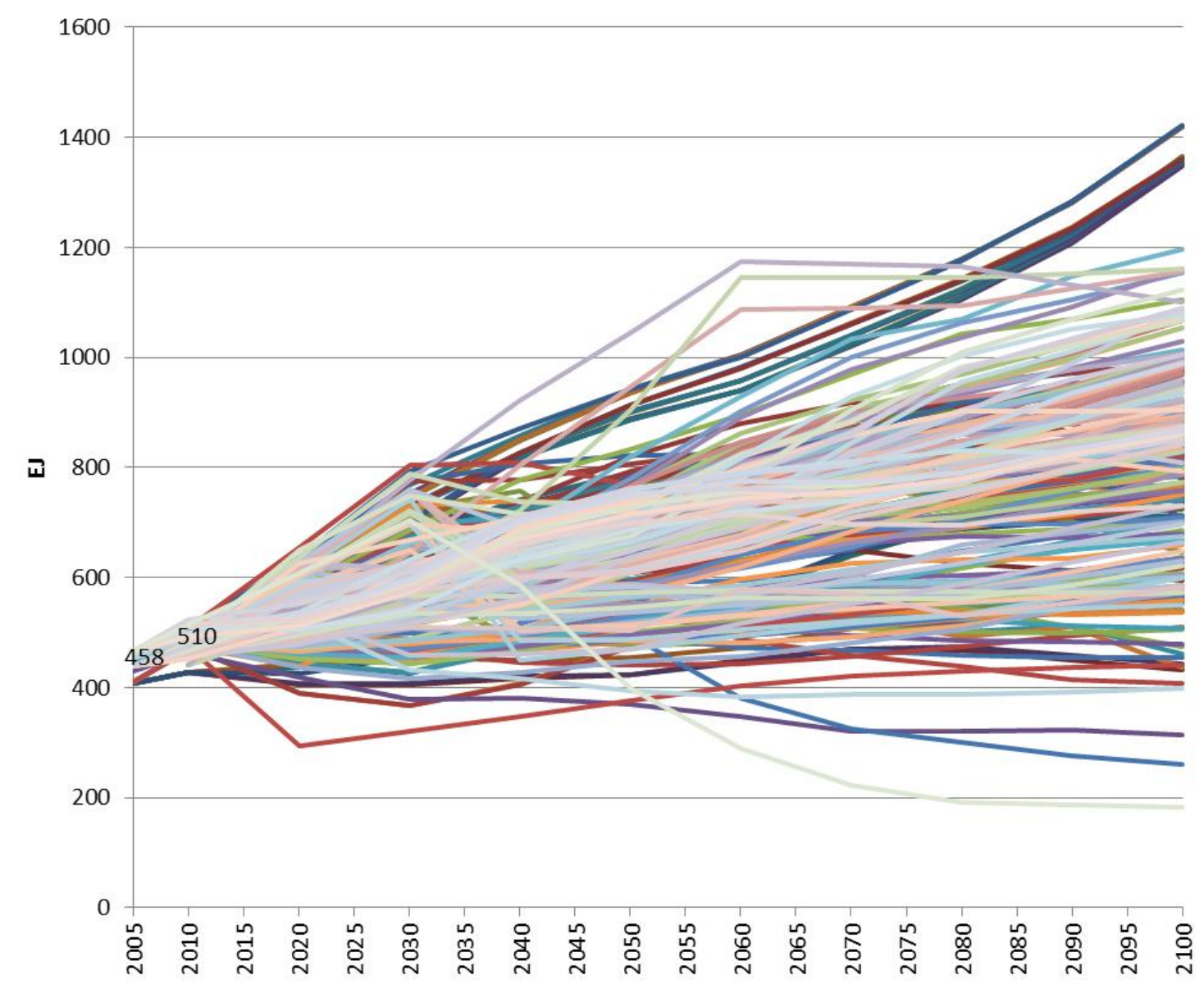

Figure 12. Global total primary energy use in the scenarios consistent with $2^{\circ} \mathrm{C}$ warming: Historic data and projections up to 2100 . Data Source: IEA ${ }^{5}$ and AR5 Scenario Database ${ }^{78}$.

The 2020 projected range is from 294 EJ to 655 EJ. The last reported corresponding historic number from IEA is $543 \mathrm{EJ}$ for 2013. These wide ranges for historic values and for relatively near-term projections do not create much confidence in the predictive capabilities for the scenarios reported by IPCC. More distant projections have even larger ranges for potential global energy futures. For example, in 2040 the range is from $352 \mathrm{EJ}$ for WITCH model ${ }^{79}$ to $921 \mathrm{EJ}$ for TIAM model ${ }^{80}$. This range between the projections almost equals to the current total global energy use. By 2100 , potential futures are even more diverse in these scenarios. The 2100 range is from $182 \mathrm{EJ}$ projected by REMIND model ${ }^{81}$ to 1421 EJ projected by GCAM model ${ }^{82}$. It should be noted that many of these scenarios are derived from the same models using different assumptions about technological development. The model with the lowest primary energy in 2100, REMIND, under different assumptions produces the result of $1122 \mathrm{EJ}$, which is closer to an upper value of the projections. The scenarios with high global primary energy numbers in 2100 are usually optimistic about electrification and development of low-carbon technologies (like nuclear, wind and solar) or negative carbon technologies (like biomass with carbon capture and storage). 
It is not obvious how one can use this information where "almost everything is possible" to inform strategic and investment decisions. One may choose information from the most trusted or reputable model, but there is no one unique metric that allows to choose "better" models. Another aspect is that there are no probabilities assigned to these scenarios. One can choose a model and carry out an uncertainty analysis by assigning probabilities to the input values of the model, like a range of possible technology costs, and derive the resulting probability density function ${ }^{83-86}$. Such uncertainty analysis is quite demanding computationally, as these models typically have hundreds of input parameters that affect substantially the energy profiles.

These longer-term energy-emission models are often simpler in their structure than the more detailed systems that serve as a basis for the annual outlooks. With an exception for the MIT model that provides its annual outlooks of the current policies $87,88,8,61$, the longer-term models usually do not provide annual updates for their projections, therefore it is harder to assess an evolution of their forecasts as was done earlier in the paper with the IEA projections from different years. There are numerous model inter-comparison exercises that are intended to illuminate the differences and robust insights obtained from different modeling approaches and different modeling groups. For example, Krey in his overview ${ }^{89}$ provides a summary of the results from numerous models that are capable of projecting energy systems and the resulting GHG emissions. Among the robust findings in his summary is that the studies are very heterogeneous in terms of the technology mix. $\mathrm{Krey}^{89}$ also stresses that the importance of the carbon capture and storage (CCS) technology for low stabilization targets has been unanimously pointed out by several modeling comparison exercises. However, the current situation with CCS deployment (where only one commercial plant in the world is currently operational) is nowhere near the projected requirements for $\mathrm{CCS}^{90-93}$. A recent UN agreement ${ }^{2}$ concluded in Paris in 2015 that has an aspirational goal of $2^{\circ} \mathrm{C}$ and a desired goal of $1.5^{\circ} \mathrm{C}$ may provide a better incentive for low-carbon technology development. Lane et al ${ }^{94}$ provide a discussion of constraints to the transformation rate of global energy infrastructure to assess the realistic rates for decarbonizing the economy. Limitations in engineering, labour, project management, material resources, and supply-chain logistics have the potential to constrain the pace at which the economy is able to transition to a low-carbon future.

Similar to a wide variation in the future energy profiles, models generally show a diverse picture for the future technology mix projections. Figure 13 illustrates the results for the power generation portfolio for several Asian countries and the OECD in 2050 in a climate policy scenario ${ }^{89}$. Different assumptions about costs and performance of individual technologies lead to dramatically different views about the future development. One conclusion from this variation in energy scenario results is that while aggressive stabilization targets require drastic changes in power generation technology options, there is no clear winner in terms of the technology. Therefore, it seems that government support for a certain type of technology (solar, or wind, or natural gas, or carbon capture and storage) is misguided. As future costs and the resulting technology mixes are uncertain, a wise government policy is to target emissions reductions from any source, rather than focus on boosting certain kinds of renewable energy. Because one might be easily (and almost certainly) wrong in picking the winning technologies, economists have long argued that carbon pricing (or carbon taxes) is the best way to ensure such an energy transformation at the lowest possible cost for society ${ }^{75,95}$. 

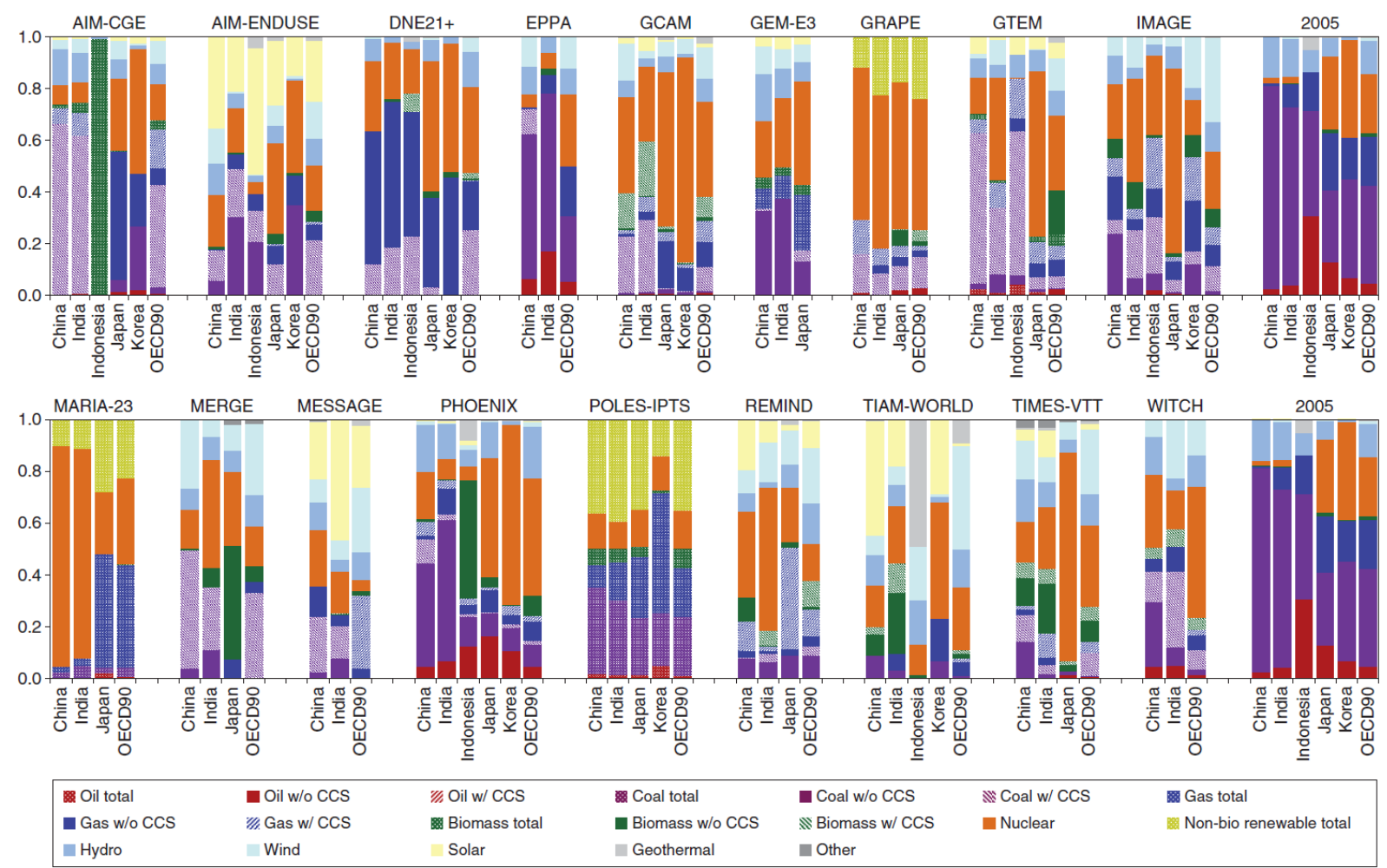

Figure 13. Electricity generation portfolio in China, India, Indonesia, Japan, Korea, and the OECD 90 across models in the $\mathrm{CO} 2$ price $\$ 30$ (5\% p.a.) scenario of the Asian Modeling Exercise in 2050. Figure source: $\mathrm{Krey}^{89}$.

An application of the energy scenarios for the climate related policy goals can be illustrated by an example of an assessment of the potential outcomes of the UN climate conference (COP-21) in Paris in 2015. Based on the modelling results from different groups, Figure 14 (prepared by the World Resources Institute ${ }^{62}$ ) presents a summary of their GHG emission projections for 2025 and 2030. This information is useful for policy makers as it shows them the current impact of the so-called intended nationally determined contributions (INDCs) that contain the countries' announcements on their plans for GHG mitigation. Projected emission levels are 51.1-57.2 $\mathrm{Gt} \mathrm{CO}_{2}$-equivalent $\left(\mathrm{CO}_{2} \mathrm{e}\right)$ in 2025 and 52-61.1 $\mathrm{Gt} \mathrm{CO}_{2} \mathrm{e}$ in $2030^{62}$, which is inconsistent with most studies that assess a likely chance of limiting warming to $2^{\circ} \mathrm{C}$. For example, $\mathrm{UN}^{96}$ finds that $\mathrm{GHG}$ emissions should be reduced to about 48 Gt CO2e in 2025 and $42 \mathrm{Gt} \mathrm{CO2e} \mathrm{in} \mathrm{2030,} \mathrm{which} \mathrm{is} \mathrm{consistent} \mathrm{with} \mathrm{numerous} \mathrm{other} \mathrm{studies}{ }^{97,98 .}$ Energy scenarios and the resulting emission profiles serve as a good indicator of the need for more aggressive mitigation actions. Emissions levels in 2025 and 2030 have significant consequences for an ability to limit warming to $2^{\circ} \mathrm{C}$ relative to preindustrial levels ${ }^{99-101}$. The higher emissions are in the near term, the greater the required emissions reductions in later decades for limiting warming. Steep rates of emissions reductions are far costlier than more gradual rates of decline ${ }^{102-104}$. 


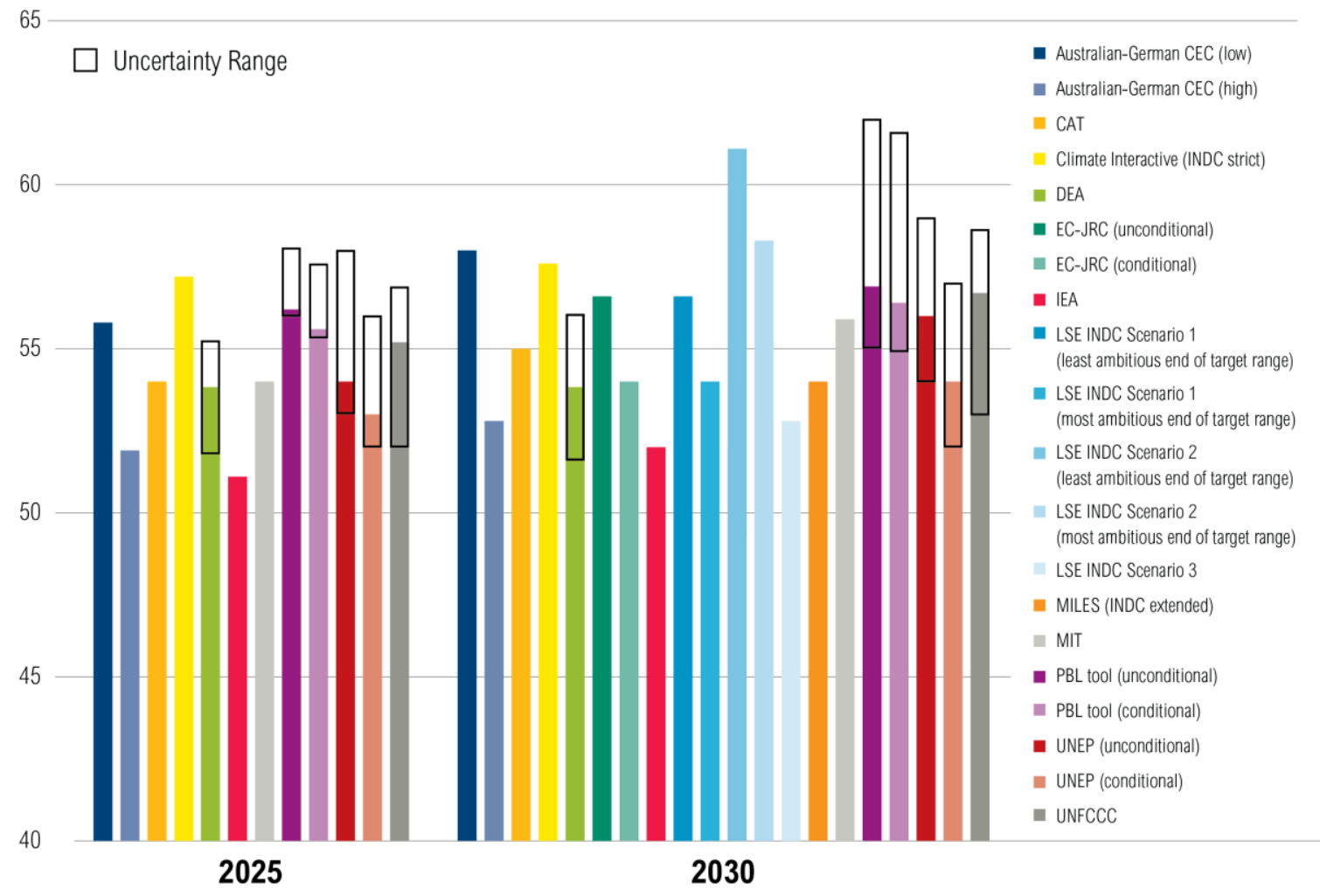

Figure 14. Greenhouse gas emissions in 2025 and 2030 resulting from actions proposed by countries for the UN climate conference in Paris (COP-21) as projected by different modelling groups. Figure source: World Resources Institute ${ }^{62}$.

\section{Conclusion}

Considering the value and limits of the energy scenarios, it is obviously easier to find the limits of the forecasts. It is true not only about the energy projections, but also about other predictions of the future: financial, economic or political. Forecasts of all sorts are usually bad at predicting sudden changes. In terms of energy projections, fast growth of China's energy appetite and its recent slowdown, fast development of unconventional oil and natural gas, fast deployment of renewables, all these events are missed by most scenarios. A move to a low-carbon energy future requires a drastic change in energy investment and the resulting mix in energy technologies. If history is any guide, energy scenarios overestimate the extent to which the future will look like the recent past.

Energy scenarios are useful for decision-makers to assess the scale of the necessary transformation. However, the exact technology mix, paths to the needed mix, price and cost projections should be treated with a great degree of caution. The scenarios are unlikely to be successful at producing precisely definitive estimates, but they can be used as a qualitative analysis of decision-making risks associated with different pathways. We should recognize the energy system is complex, 
interconnected and affected by economic drivers. In turn, economists are notorious for their forecasting ability. As John Kenneth Galbraith once said, "Economists make prediction not because they know, but because they are asked." Due to a long-lasting nature of energy infrastructure, energy system is not as fluid as economic system, and some trajectories in energy development are more persistent, but the same degree of carefulness should be applied to the long-term energy forecasts as to economic forecasts. Energy scenarios models are complex, but they do not reflect all the complexity, so they often provide imprecise projections. At the same time, without models nothing at all constrains the projections.

While indeed energy scenarios are not suited for providing the exact number (or specific forecast), but practically decisions have to be made. The value of energy scenarios (and models that produce them) is not in their decision-making capabilities, but in their decision-support capabilities. Any single energy scenario is not going to provide a prediction of the future, and it cannot be used as a basis for policy-making. However, the results from numerous scenarios obtained from different modelling planforms provide useful information about potential risks and benefits of a particular potential policy or investment.

When one has a model to make a scenario - an argument can be made about improvement, simplification, or bringing additional details. When one has just tea leaves to guess the future, there is no tool to advance the knowledge. Most of the energy scenarios offer plausible rather than most likely future. Perhaps the most important uncertainty about the future of energy is its interaction with the environment. The need for low-emitting technologies will shift the current technology mix, but the exact contribution of particular technology and the timing of this shift depend on many economic and political variables. Such uncertainty about the future costs and technologies supports a conclusion that governments should not try to pick the "winners", rather the policy and investment focus should be on targeting emissions reductions from any energy source. Energy scenarios may not provide the exact projections, but they are the best available tool to assess the magnitude of challenges that lie ahead.

\section{Acknowledgement}

The author is thankful to Lisa Brodsky for an opportunity to provide this review and to Elena Kalinina for her valuable contribution with preparation of this manuscript. Support from the MIT Center for Energy and Environmental Policy Research (CEEPR) is greatly appreciated. MIT CEEPR is jointly sponsored by the MIT Sloan School of Management, the MIT Department of Economics, the MIT Energy Initiative, and CEEPR Associates (the list of associates is available at:

http://ceepr.mit.edu/ceepr-associates/). MIT Joint Program on the Science and Policy of Global Change, where the author is employed, is supported by a consortium of government, industry and foundation sponsors, including U.S. Department of Energy, Office of Science (DE-FG02-94ER61937). For a complete list of sponsors see http://globalchange.mit.edu/sponsors/current.html 


\section{References}

1. UN. Kyoto Protocol to the United Nations Framework Convention on Climate Change. United Nations; 1998 (http://unfccc.int/resource/docs/convkp/kpeng.pdf).

2. UNFCCC. Adoption of the Paris Agreement. United Nations Framework Convention on Climate Change; 2015 (http://unfccc.int/resource/docs/2015/cop21/eng/109r01.pdf).

3. EIA. Annual Energy Outlook 2015. Washington, DC: U.S. Energy Information Administration; 2011.

4. IEA. Africa Energy Outlook: A Focus on Energy Prospects in Sub-Saharan Africa. Paris: International Energy Agency; 2014.

5. IEA. World Energy Outlook 2015. Paris: International Energy Agency; 2015.

6. Paltsev S, Scenarios for Russia's Natural Gas Exports to 2050. Energy Econ 2014, 42:262-270.

7. Shell. New Lens Scenarios. London, UK: Shell; 2013. (http://www.shell.com/global/futureenergy/scenarios/new-lens-scenarios.html).

8. MIT Joint Program. 2014 Energy and Climate Outlook. Cambridge, MA: MIT Joint Program on the Science and Policy of Global Change; 2014.

9. EIA, 2015 August Short-Term Energy Outlook. Washington, DC: U.S. Energy Information Administration; 2015.

10. Capros P, Mantzos L. The European Energy Outlook to 2010 and 2030. Int J Global Energy Issues 2000, 14:137-154.

11. US CCSP, Scenarios of Greenhouse Gas Emissions and Atmospheric Concentrations. Washington, DC: U.S. Climate Change Science Program, U.S. Department of Energy, Office of Biological and Environmental Research; 2007.

12. Clarke L, Edmonds J, Krey V, Richels R, Rose S, Tavoni M. International climate policy architectures: overview of the EMF 22 international scenarios. Energy Econ 2009, 31:S64-S81.

13. WEC. World Energy Scenarios: Composing Energy Futures to 2050. London, UK: World Energy Council; 2013.

14. ExxonMobil. The Outlook for Energy: A View to 2040. Irvin, TX: ExxonMobil Corporation; 2015.

15. BP, Energy Outlook 2035. London, UK: BP; 2015.

16. OPEC, World Oil Outlook 2010. Vienna, Austria: Organization of the Petroleum Exporting Countries; 2010.

17. IEA. Energy and Climate Change: World Energy Outlook Special Report. Paris: International Energy Agency; 2015. 
18. Clarke L, Jiang K, Akimoto K, Babiker M, Blanford G, Fisher-Vanden K, Hourcade J, Krey V, Kriegler E, Löschel A, et al. Assessing Transformation Pathways, in Climate Change 2014: Mitigation of Climate Change. Contribution of Working Group III to the Fifth Assessment Report of the Intergovernmental Panel on Climate Change. Cambridge: Cambridge University Press; 2014.

19. OECD. OECD Economic Outlook. Paris: Organisation for Economic Co-operation and Development; 2015.

20. Russian Energy Agency. Global and Russian Energy Outlook until 2035. Moscow: Russian Energy Agency; 2012.

21. MIT. The Future of Coal. Cambridge, MA: Massachusetts Institute of Technology; 2003.

22. Jensen J. The Impact of Low Oil Prices on International Markets. Weston, MA: Jensen Associates; 2015.

23. MIT. The Future of Natural Gas. Cambridge, MA: Massachusetts Institute of Technology; 2011.

24. IEA. World Energy Model Documentation, 2014 Version. Paris: International Energy Agency; 2014.

25. IMF. World Economic Outlook 2015. Washington, DC: International Monetary Fund; 2014

26. UN. World Population Prospects: The 2012 Revision. New York: UN Department of Economic and Social Affairs, United Nations; 2013.

27. Holz F, von Hirschhausen C, Kemfert C. A strategic model of European gas supply (GASMOD), Energy Economics 2008, 30:766-788.

28. Manne A, Richels R. MERGE: An Integrated Assessment Model for Global Climate Change. Palo Alto: Stanford University; 2004.

29. Delarue E, Morris J. Renewables Intermittency: Operational Limits and Implications for Long-Term Energy System Models. Report 277, Cambridge: MIT Joint Program on the Science and Policy of Global Change; 2015.

30. Loulou R, Goldstein G, Noble K. Documentation for the MARKAL Family of Models. Ottawa, Canada: Energy Technology Systems Analysis Programme; 2004 (http://www.etsap.org/tools.htm).

31. Short W, Sullivan P, Mai T, Mowers M, Uriarte C, Blair N., et al. Regional Energy Deployment System (ReEDS). Technical Report NREL/TP-6A20-46534. Golden, CO: National Renewable Energy Laboratory; 2011 (http://www.nrel.gov/analysis/reeds/pdfs/reeds_documentation.pdf).

32. Messner S. Endogenized Technological Learning in an Energy Systems Model, Journal of Evolutionary Economics 1997, 7:291-313. 
33. Nordhaus W. The 'DICE' Model: Background and Structure of a Dynamic Integrated ClimateEconomy Model of the Economics of Global Warming. Discussion Paper 1009, New Haven: Yale University; 1992 (http://cowles.econ.yale.edu/P/cd/d10a/d1009.pdf).

34. Nordhaus W, Yang, Z. A Regional Dynamic General-Equilibrium Model of Alternative ClimateChange Strategies. American Economic Review 1996, 86: 741-765.

35. Popp D. ENTICE: Endogenous Technological Change in the DICE Model of Global Warming. Journal of Environmental Economics and Management, 2004, 48: 742-768.

36. Paltsev S, Reilly J, Jacoby H, Eckaus R, McFarland J, Sarofim M, et al. The MIT Emissions Prediction and Policy Analysis (EPPA) Model: Version 4. Report 125, Cambridge: MIT Joint Program on the Science and Policy of Global Change; 2005

(http://globalchange.mit.edu/files/document/MITJPSPGC_Rpt125.pdf).

37. Ross M. Documentation of the Applied Dynamic Analysis of the Global Economy (ADAGE) Model. Working Paper 07-02, Research Triangle Park: Research Triangle Institute; 2007 (http://www.rti.org/pubs/adage-model-doc_ross_apr07.pdf).

38. Hertel T. Global Trade Analysis: Modeling and Applications. Cambridge: Cambridge University Press; 1997

39. IEA. World Energy Outlook 1994 Edition. Paris: International Energy Agency; 1994.

40. IEA. World Energy Outlook 1995 Edition. Paris: International Energy Agency; 1995.

41. IEA. World Energy Outlook 1996 Edition. Paris: International Energy Agency; 1996.

42. IEA. World Energy Outlook 1998 Edition. Paris: International Energy Agency; 1998.

43. IEA. World Energy Outlook 1999 Insights. Paris: International Energy Agency; 1999.

44. IEA. World Energy Outlook 2000. Paris: International Energy Agency; 2000.

45. IEA. World Energy Outlook, Assessing Today's Supplies to Fuel Tomorrow's Growth, 2001 Insights. Paris: International Energy Agency; 2001.

46. IEA. World Energy Outlook 2002. Paris: International Energy Agency; 2002.

47. IEA. World Energy Investment Outlook, 2003 Insights. Paris: International Energy Agency; 2003.

48. IEA. World Energy Outlook 2004. Paris: International Energy Agency; 2004.

49. IEA. World Energy Outlook 2005, Middle East and North Africa Insights. Paris: International Energy Agency; 2005.

50. IEA. World Energy Outlook 2006. Paris: International Energy Agency; 2006.

51. IEA. World Energy Outlook 2007, China and India Insights. Paris: International Energy Agency; 2007. 
52. IEA. World Energy Outlook 2008. Paris: International Energy Agency; 2008.

53. IEA. World Energy Outlook 2009. Paris: International Energy Agency; 2009.

54. IEA. World Energy Outlook 2010. Paris: International Energy Agency; 2010.

55. IEA. World Energy Outlook 2011. Paris: International Energy Agency; 2011.

56. IEA. World Energy Outlook 2012. Paris: International Energy Agency; 2012.

57. IEA. World Energy Outlook 2013. Paris: International Energy Agency; 2013.

58. IEA. World Energy Outlook 2014. Paris: International Energy Agency; 2014.

59. Château J., Dellink R, Lanzi E. An Overview ofthe OECD ENV-Linkages Model: Version 3, OECD Environment Working Papers No. 65, Paris: OECD Publishing; 2014.

60. EIA. International Energy Outlook 2014. Washington, DC: Energy Information Administration; 2014.

61. MIT Joint Program. Energy and Climate Outlook: Perspectives from 2015, Cambridge, MA: MIT Joint Program on the Science and Policy of Global Change; 2015.

62. Levin K, Franses T. Why Are INDC Studies Reaching Different Temperature Estimates? Washington, DC: World Resources Institute; 2015 (http://www.wri.org/blog/2015/11/insiderwhy-are-indc-studies-reaching-different-temperature-estimates).

63. Paltsev S. Implications of Alternative Mitigation Policies on World Prices for Fossil Fuels and Agricultural Products, World Institute for Development Economic Research, Working Paper 2012/65, Helsinki, Finland: United Nations University; 2012 (https://www.wider.unu.edu/sites/default/files/wp2012-065.pdf).

64. EIA. International Energy Outlook 2010. Washington, DC: Energy Information Administration; 2010.

65. EIA. International Energy Outlook 2011. Washington, DC: Energy Information Administration; 2011.

66. EIA. International Energy Outlook 2013. Washington, DC: Energy Information Administration; 2013.

67. MIT. The Future of Solar Energy: An Interdisciplinary MIT Study, Cambridge MA: Massachusetts Institute of Technology; 2015.

68. EPRI. Levelized Cost of Electricity and Non-Dispatchable Generation. Palo Alto: Electric Power Research Institute; 2015.

69. Joskow P. Comparing the Costs of Intermittent and Dispatchable Electricity Generating Technologies. American Economic Review 2011, 101:238-41. 
70. IEA. The Power of Transformation: Wind, Sun and the Economics of Flexible Power Systems, Paris: International Energy Agency; 2014.

71. Edmonds J, Reilly J. Global Energy: Assessing the Future, Oxford: Oxford University Press; 1985

72. Bosetti V, Carraro C, Galeotti M, Massetti E, Tavoni M. WITCH: A World Induced Technical Change Hybrid Model. The Energy Journal, Special Issue on Hybrid Modeling of EnergyEnvironment Policies: Reconciling Bottom-up and Top-down, 2006, 13-38.

73. Paltsev S, Monier E, Scott J, Sokolov A, Reilly J. Integrated Economic and Climate Projections for Impact Assessment. Climatic Change 2015, 131:21-33.

74. van Vuuren D, Smith S, Riahi K. Downscaling socioeconomic and emissions scenarios for global environmental change research: a review. WIREs: Clim Change 2010, 1:393-404.

75. Paltsev S, Karplus V, Chen H, Karkatsouli I, Reilly J, Jacoby H. Regulatory Control of Vehicle and Power Plant Emissions: How Effective and at What Cost? Climate Policy 2015, 15:438-457.

76. Lund P. The European Union challenge: integration of energy, climate, and economic policy. WIREs Energy Environ 2012, 1:60-68.

77. IPCC. Climate Change 2014: Mitigation of Climate Change. Contribution of Working Group III to the Fifth Assessment Report of the Inter-governmental Panel on Climate Change. Cambridge: Cambridge University Press; 2007.

78. IIASA. IAMC AR5 Scenario Database. Laxenburg, Austria: International Institute for Applied Systems Analysis; 2014 (https://secure.iiasa.ac.at/web-apps/ene/AR5DB/).

79. Bosetti V, Carraro C, Tavoni M. Climate change mitigation strategies in fast-growing countries: The benefits of early action. Energy Economics 2009, 31(Supplement 2): S144-S151.

80. Loulou R, Labriet M, Kanudia A. Deterministic and stochastic analysis of alternative climate targets under differentiated cooperation regimes. Energy Economics 2009, 31(Supplement 2): S131-S143.

81. Bauer N, Mouratiadou I, Luderer G, Baumstark L, Brecha R, Edenhofer O, Kriegler E. Global fossil energy markets and climate change mitigation - an analysis with REMIND. Climatic Change In Press.

82. Calvin K, Edmonds J, Bond-Lamberty B, Clarke L, Kim S, Kyle P, Smith S, Thomson A, Wise M (2009). 2.6: Limiting climate change to 450 ppm CO2 equivalent in the 21st century. Energy Economics 2009, 31(Supplement 2): S107-S120.

83. Sokolov A, Stone P, Forest C, Prinn R, Sarofim M, Webster M, Paltsev S, Schlosser A, Kicklighter D, Dutkiewicz S, Reilly J, Wang C, Felzer B, Jacoby H. Probabilistic Forecast for 21st Century Climate Based on Uncertainties in Emissions (Without Policy) and Climate Parameters. Journal of Climate 2009, 22:5175-5204. 
84. Webster M, Sokolov A, Reilly J, Forest C, Paltsev S, Schlosser A, Wang C, Kicklighter D, Sarofim M, Melillo J, Prinn R, Jacoby H. Analysis of Climate Policy Targets under Uncertainty. Climatic Change 2012, 112:569-583.

85. Wigley T, Clarke L, Edmonds J, Jacoby H, Paltsev S, Pitcher H, Reilly J, Richels R, Sarofim M, Smith S. Uncertainties in Climate Stabilization. Climatic Change 2009 97:85-121.

86. Gillingham K, Nordhaus W, Anthoff D, Blanford G, Bosetti V, Christensen P, McJeon H, Reilly J, Sztorc P. Modeling Uncertainty in Climate Change: A Multi-Model Comparison, Report 290, Cambridge: MIT Joint Program on the Science and Policy of Global Change; 2015 (http://globalchange.mit.edu/files/document/MITJPSPGC_Rpt290.pdf).

87. MIT Joint Program. 2012 Energy and Climate Outlook, Cambridge, MA: MIT Joint Program on the Science and Policy of Global Change; 2012.

88. MIT Joint Program. 2013 Energy and Climate Outlook, Cambridge, MA: MIT Joint Program on the Science and Policy of Global Change; 2013.

89. Krey V. Global energy-climate scenarios and models: a review. WIREs Energy Environ 2014, 3:363-383.

90. Reiner D. Learning through a portfolio of carbon capture and storage demonstration projects. Nature Energy, In Press.

91. Herzog H. Scaling up Carbon Dioxide Capture and Storage: From Megatons to Gigatons. Energy Economics 2011, 33:597-604.

92. Herzog H. What Future for Carbon Capture and Sequestration? Environmental Science and Technology 2001, 35:148-153.

93. Lupion M, Herzog H NER300: Lessons learnt in attempting to secure CCS projects in Europe. International Journal of Greenhouse Gas Control 2013, 19:19-25.

94. Lane J, Smart S, Schmeda-Lopez D, Hoegh-Guldberg O, Garnett A, Greig C, McFarland E. Understanding constraints to the transformation rate of global energy infrastructure, WIRES Energy Environ 2015.

95. Rausch S, Karplus V. Markets versus Regulation: The Efficiency and Distributional Impacts of U.S. Climate Policy Proposals. Energy Journal 2014, 35(SI1):199-227.

96. UNEP. The Emissions Gap Report 2014, New York: United Nations Environment Programme; 2014.

97. Prinn R, Paltsev S, Sokolov A, Sarofim M, Reilly J, Jacoby H. Scenarios with MIT Integrated Global Systems Model: Significant Global Warming Regardless of Different Approaches. Climatic Change 2011, 104: 515-537. 
98. Allen M, Barros V, Broome J, Cramer W, Christ R, Church J, Clarke L, Dahe Q, Dasgupta P, Dubash N. IPCC fifth assessment synthesis report-climate change 2014: synthesis report. Cambridge: Cambridge University Press; 2014 (http://www.ipcc.ch/report/ar5/wg3/).

99. van Vuuren $D$, Riahi K. The relationship between short-term emissions and long-term concentration targets. Climatic Change 2011, 104:793-801.

100. den Elzen $M$, van Vuuren D. Peaking profiles for achieving long-term temperature targets with more likelihood at lower costs. Proc Natl Acad Sci 2007, 104:17931-17936.

101. Meinshausen M, Meinshausen N, Hare W, Raper S, Frieler K, Knutti R, Frame D, Allen M.

Greenhouse-gas emission targets for limiting global warming to 2C. Nature 2009, 458:1158-1162.

102. Krey V, Riahi K. Implications of delayed participation and technology failure for the feasibility, costs, and likelihood of staying below temperature targets - greenhouse gas mitigation scenarios for the $21^{\text {st }}$ century. Energy Economics 2009, 31:S94-S106.

103. Kriegler E, Weyant J, Blanford G, Krey V, Clarke L, Edmonds J, Fawcett A, Luderer G, Riahi K, Richels $\mathrm{R}$, et al. The role of technology for achieving climate policy objectives: overview of the EMF27 study on global technology and climate policy strategies. Climatic Change 2014, 123:353367.

104. van Vliet J, Hof A, Mendoza Beltran A, van den Berg M, Deetman S, den Elzen M, Lucas P, van Vuuren $\mathrm{D}$. The impact of technology availability on the timing and costs of emission reductions for achieving long-term climate targets. Climatic Change 2014, 123:559-569.

105. MacCracken M. Prediction versus Projection - Forecast versus Possibility. Weatherzine 2001, 26 (http://sciencepolicy.colorado.edu/zine/archives/1-29/26/guest.html). 